\title{
THE EFFECT OF DIFFERENT IRRIGATION REGIMES ON FLORET AND ROOT ANATOMY OF AEROBIC RICE GENOTYPES IN KHUZESTAN, IRAN
}

\author{
LIMOUCHI, K. ${ }^{1}-$ YARNIA, M. $^{1 *}-$ SIYADAT, A. ${ }^{2}-$ RASHIDI, V. ${ }^{1}-$ GUILANI, A. ${ }^{3}$ \\ ${ }^{I}$ Department of Agronomy, Faculty of Agriculture, Tabriz Branch, Islamic Azad University \\ Tabriz, Iran \\ ${ }^{2}$ University of Agricultural and Natural Resources of Ramin \\ Ahwaz, Iran
}

${ }^{3}$ Seed and Plant Improvement Research Department, Khuzestan Agricultural and Natural Resources Research Center, AREEO Ahwaz, Iran

*Corresponding author e-mail:yarnia@iaut.ac.ir

(Received $18^{\text {th }}$ Jul 2017; accepted $19^{\text {th }}$ Oct 2017)

\begin{abstract}
The aim of this study was to examine the effect of different planting regimes on anatomical traits of floret and root effective on productivity and seed hollowness as well as grain yield of 12 aerobic rice genotypes in subplots under the influence of four different irrigation regimes (irrigation intervals of $1,3,5$ and 7 days) in the main plots by split-plot based on randomized complete block with three replications for two years (2014 and 2015) in Khuzestan. Results of combined analysis showed that there were significant differences in all parameters between genotypes, irrigation regimes and the interaction of the two factors except for the stigma length and the central cylindrical area of roots. Reduction of the amount of irrigation had decreased central cylindrical area and xylem of root in order to increase efficiency and maintain the water potential in plants. The highest length of anthers and stigmas was observed in the 5-day irrigation regime and maximum width of anthers, style length and pollen area was observed in the 3-day irrigation regime and the genotypes had the highest grain yield $(5094.31 \mathrm{~kg} / \mathrm{ha}) \mathrm{due}$ to the ideal conditions. Therefore, it can be concluded that by focusing revision goals on reducing the central cylinder and xylem areas in order to increase the efficiency of irrigation water in terms of reduced irrigation and controlling lengths of florets parts we can hope to increase connection between pollen and flower and finally fertility to increase production under different irrigations.
\end{abstract}

Keywords: rice, irrigation regimes, anatomy, cluster, floret

\section{Introduction}

Rice is one of the oldest cultivation plants (Ghosh and Chakma, 2015) and is the main food of more than half the world's population (Park et al., 2014). Drought is a serious risk for the successful production of major crops in the world, especially rice, which can occur at any time during the growing season. Hence, one of the main challenges in agriculture Is to produce more food with less water (Tuyen and Prasad, 2008). Seventy percent of world's fresh water is consumed in agriculture, which 25 to 30 percent of this amount is devoted to rice cultivation (Sedaghat et al., 2015). Rice has the greatest amount of water consumption among agricultural products and about $80 \%$ of Asia's fresh water is used for this (Sedaghat et al., 2015). Almost 75\% of world's rice is obtained from irrigated rice paddies (Carmelita et al., 2011). Irrigation with few days interval provides enough oxygen for the plant root system, which this would accelerate the mineralization of organic matter and soil nitrogen-fixing. All of these improve 
increasing in the plant nutrients and thus increase its growth (Dong et al., 2012). Lack of moisture is one of the most important growth limiting factors (Mosavy et al., 2016). Intermittent irrigation management can provide plant needs in crisis situations (Shanmugasundaram, 2015). The main advantage of intermittent irrigation with intervals of few days is savings in water consumption (Uphoff et al., 2013). Limuchi et al. (2014) reported the reduction of growth period length in order to decrease the unstructured carbohydrates to the main tank, i.e. grain, as an important factor in reduced yield (Limuchi et al., 2014).

Anatomical changes in plants under environmental stress can reduce the vascular bundles area such as Xylem area, which the result of these changes can protect cells from death and dieback (Mostajeran et al., 2008).

There was a difference in terms of pollen germination at times after anthers' opening. Variety Minyhui 63 had the highest germination rate $(85 \%)$ at time 0 or immediately after anthers' opening; But variety Rufipogon with lower germination rate $(60 \%), 50 \%$ of pollens were alive after 12 min (longer). The lowest germination rate (34\%) was observed in hybrid varieties with an average longevity that more than $50 \%$ were alive after $10 \mathrm{~min}$ even after $40 \mathrm{~min}$ (Song et al., 2001). Uniformity between opening of florets and anthers causes high self-pollination in rice, but stressful situations at the time of flowering can postpone the turgidity and growth of pollens (Matsui et al., 2000). Matsui and Hisashi (2003) showed that there were positive correlation between the number of pollen on stigma and morphological characteristics.

Many researches were carried out on the root structure and its effect on yield in drought conditions and the structural changes and root anatomy were studied in irrigation conditions and the best cross-section due to irrigation conditions for example, increasing and decreasing cross-section in order to increase water absorption and increase efficiency in drought conditions and selection should be done from genotypes with small cross-section in order to increase water use efficiency in root (Lopes and Reynolds, 2010; Hamadanzadah et al., 2015). It should be stated the management practices of different irrigation should be overcome to increase the volume and finally cross-section of root (Sadranasab et al., 2014). In terms of root characteristics it can be stated that the desirable root characteristics change with different irrigation conditions and modification to increase cross-section, central cylinder and xylem of root to absorb more water in favorable irrigation conditions (Zhou et al., 2007; Moshafaghi et al., 2014). The root is the only organ in direct contact with the surrounding soil, so having an efficient xylem bundles and central cylinder appropriate to the circumstances and anatomical changes in order to organs adaption according to previous statements can have an effective role in dealing with decreased water or watering more than plants need in line with the absorption of nutrients and minerals and finally can fill the main plant reservoir, i.e. grains (Sadat Jamali et al., 2014; Shelden et al., 2013). To increase their survival under conditions of drought and temperatures, plants change anatomically such as reduced vascular bundles area for better compatibility with the environment (Ghorbani et al., 2011).

Increased drought to maintain the water potential in plant causes a reduction in diameter of Xylem vascular bundles (Majd et al., 2009). Xylem vascular bundles area decreases in different conditions leading to water stress in order to improve irrigation efficiency and to maintain plant water potential (Limouchi and Farahvash, 2014). Stresses can decrease vascular bundles area and diameter to improve water use efficiency and to reduce transpiration, while these traits are positively and significantly 
correlated to grain yield (Limouchi, et al., 2013). Water shortage for rice leads to a reduction in the value of anatomical traits effective in water retention and movement such as vascular bundles to maintain the amount of water in rice (Daxylem, 2016).

This study aimed to identify the tolerance and sensitivity mechanisms to drought in different irrigation intervals in order to increase florets fertility and reduce hollowness as well as to study changes in anatomical characteristics of roots.

\section{Materials and methods}

This study aimed to reduce and optimize water consumption and increase irrigation efficiency in split-plots by two factors and 3 replications in a randomized complete block design by upland rice method $(3 \times 4 \mathrm{~m}$ plots) for two years $(2014$ and 2015) in Shavoor Agricultural Research Station of Agriculture and Natural Resources Research Center of Iran in Khuzestan province at $70 \mathrm{~km}$ north of Ahvaz between the rivers of Karkhe and Karun ( $31^{\circ} 50^{\prime}$ latitude and $48^{\circ} 28^{\prime}$ longitude, $33 \mathrm{~m}$ above sea level). Farm soil texture was loamy-clay with $\mathrm{pH}=7-7.5$ and electrical conductivity of 2.5 $\mathrm{mmhos} / \mathrm{cm}$, and amounts of nitrogen, phosphorus, potassium and zinc were $0.09 \%, 10-$ 12, 120 and $2.5 \mathrm{ppm}$, respectively. Four irrigation regimes include intermittences of one-day or control (common in the region) (I1), 3 (I2), five (I3) and seven days (I4) as main factor levels and 12 rice genotypes were places in subplots (Table 1).

Table 1. Some features and pedigree of the genotypes used in the study

\begin{tabular}{c|c|c|c}
\hline Genotype & Cross & Origin & Drought Tolerance \\
\hline VANDANA & C 22/KALAKERI & INDIA & 1 \\
IR 78908-193-B-3-B & VANDANA/IR 65 & IRRI & 1 \\
IR 81429-B-31 & IR 78908-44/IR 78908-86 & IRRI & 1 \\
IR 78875-176-B-1-B & PSB RC 9/IR 64 & IRRI & 3 \\
IR 79971-B-202-2-4 & VANDANA/WAYRAREM & IRRI & 5 \\
IR 80508-B-194-4-B & PSB RC 9/AUS 257 & IRRI & 7 \\
IR 80508-B-194-3-B & PSB RC 9/AUS 257 & IRRI & 5 \\
IR 79907-B-493-3-1 & IR 55419-04/IR 64 & IRRI & 5 \\
IR 81025-B-347-3 & NSIC RC 140/IR 74371-3-1-1 & IRRI & 5 \\
IR 81025-B-327-3 & NSIC RC 140/IR 74371-3-1-1 & IRRI & 3 \\
NADA & AMOL $/$ SANG TARAM & IRAN & 3 \\
TAROM & - & IRAN & 9 \\
\hline
\end{tabular}

The numbers from 1 to 9 have the highest and lowest drought tolerance, respectively.

After soil preparation, dry seeds of each genotype were sown in $20 \mathrm{~cm}$ rows by a Hamadani farmer and then irrigation regimes were applied since the mid-tillering. Plots were irrigated to a height of $5 \mathrm{~cm}$ with water supplied by a pump and then irrigation stopped. This trend was applied for whole growing season and all four treatments. To prevent water infiltration into adjacent plots, all stacks to a depth of $1 \mathrm{~m}$ into the soil and irrigation streams' walls were covered by a plastic. Irrigation regimes were selected according to the conditions and potential of water and the amount of water entering the plots was determined according to the water height and plots' size during irrigation, which was about $7 \mathrm{~h}$, as well as regarding the water discharge. Some meteorological 
parameters are shown in Table 2. To provide nutrients; nitrogen of urea source was used by 200 and $300 \mathrm{~kg} / \mathrm{ha}$ as $25 \%$ baseline (20-25 days after emergence) and the remaining $75 \%$ in three times $(25 \%)$ as first to third first input respectively in the first bud cluster formation ( 35 to 40 days after using baseline fertilizer), The seed formation (30-35 days after the first first input) and $50 \%$ in time of the emergence of clusters $50 \mathrm{~kg}$ of phosphorus fertilizer per ha from triple superphosphate source, $100 \mathrm{~kg}$ of potash fertilizer and $40 \mathrm{~kg}$ zinc per ha from sulfate source were used in the soil. Integrated weed control including weeding and using 2,4-D pesticide (1.5-2 L/ha; 35 to 40 days after emergence) was applied. The following traits were studied.

Table 2. The minimum and maximum average of monthly temperature (sowing to harvesting) in Shavoor Agricultural Research Station for two years (2014 and 2015)

\begin{tabular}{c|c|c|c|c}
\hline \multirow{2}{*}{ Month } & \multicolumn{2}{|c|}{$(\mathbf{2 0 1 5})$} & \multicolumn{2}{|c}{$(\mathbf{2 0 1 4})$} \\
\cline { 2 - 5 } & Mean min. $\left({ }^{\circ} \mathbf{C}\right)$ & Mean min. $\left({ }^{\circ} \mathbf{C}\right)$ & Mean min. $\left({ }^{\circ} \mathbf{C}\right)$ & Mean min. $\left({ }^{\circ} \mathbf{C}\right)$ \\
\hline Jun. & 26 & 44 & 26.6 & 46.2 \\
Jul. & 27.8 & 46.7 & 27.8 & 45.7 \\
Aug. & 27.8 & 46.5 & 29.1 & 47.5 \\
Sep. & 25.2 & 44.5 & 27.4 & 44.6 \\
Oct. & 21 & 38 & 22.2 & 39.5 \\
Nov. & 12.7 & 29 & 15.8 & 27.8 \\
\hline Average & 23.42 & 41.45 & 24.82 & 41.88 \\
\hline
\end{tabular}

Matsui and Omasa method (Matsui and Omasa, 2002) was used to determine the length and width of anthers as well as length of stigma and style. One day before the opening of florets, $1 / 3$ of florets from the tip of first cluster branch (18 anthers from three florets) were collected for each variety. Measurements were done under a microscope after stabilizing in F.A.A mix (Formalin-acetic acid-alcohol). Anther length from longer side of anther sac and anther width from average of two sides, one parallel to anther wall that opens after maturity (W1) and the other perpendicular to it (W2), were taken. Measuring length of stigma and style and counting pollen on the stigma were performed after staining 15 florets with Cotton blue for $15 \mathrm{~min}$. Then stained samples were placed on a lamel to prepare images and traits were measured with a light microscope with a magnification of 40. Length of stigma and style were measured from the tip of stigma to the junction with style and from base of stigma to the junction with ovary, respectively. Viability, diameter and area of pollens were determined by using the Erie classification system based on their shape and staining with potassium iodide (Anonymous, 1982).

For the measurement of anatomical traits, roots were taken out of the soil at the time heading and then $2-3 \mathrm{~cm}$ slices in middle parts were prepared. F.A.A solution was used to store samples. Cross- section and thin slices were manually prepared using Styrofoam and to stain cross- sections of roots in order to observe and measure the central cylindrical area and xylem, samples were washed with distilled water and placed in bleach for $15 \mathrm{~min}$ and then in Carmen Zaji for $20 \mathrm{~min}$ and finally in green methyl for 10-15 s and they were washed thoroughly with distilled water between each stage. Then stained samples were placed on a lamel to prepare images and traits were measured with a light microscope with a magnification of 40 (Limouchi, 2013). 
Measurement of the grain yield at $14 \%$ moisture (the moisture after harvest) was done after reaching $85 \%$ grain in harvest cluster in an area of $1.5 \mathrm{~m}^{2}$ in the middle of each plot and removing borders.

Dry matter per ha (after placement of samples without base for $72 \mathrm{~h}$ in an oven), fertility rate (the ratio of filled florets to total florets) and the weight of one thousand seeds by randomly picking 30 main clusters from each replication were measured.

All data obtained from the study after ensuring normality were analyzed using analysis of variance (combined) and correlation in SAS and SPSS and Duncan test was used for mean comparison of data at $5 \%$ level.

\section{Results and discussion}

\section{Anther length}

In this study, it was found that there were significant differences between years, irrigation regimes and genotypes and the interaction of irrigation regimes and genotypes at $1 \%$ level and also between the interaction of years and genotypes and interaction of years, irrigation regimes and genotypes at 5\% level; but other factors were not significantly different (Table 3).

Table 3. Combined analysis results of floret anatomical characteristics in study treatments

\begin{tabular}{|c|c|c|c|c|c|c|}
\hline & & \multicolumn{5}{|c|}{ MS } \\
\hline S.O.V & df & $\begin{array}{l}\text { Anther } \\
\text { width }\end{array}$ & $\begin{array}{l}\text { Anther } \\
\text { length }\end{array}$ & $\begin{array}{l}\text { Stigma } \\
\text { length }\end{array}$ & Style length & Pollen area \\
\hline Year & 1 & $401120.641^{* *}$ & $41744.216^{* * *}$ & $558912.021^{* *}$ & $52604.333^{* *}$ & $189216.370^{* * *}$ \\
\hline Rep. (year)(error a) & 4 & 258802.043 & 17987.262 & 239490.315 & 18758.126 & 153330.443 \\
\hline Irrigation regimes & 3 & $59824.894^{* *}$ & $26521.502^{* *}$ & $8291.879^{*}$ & $4704.412^{* *}$ & $180214.624^{* *}$ \\
\hline Irrigation regimes $\times$ year & 3 & $1421.210^{\mathrm{ns}}$ & $130.924^{\mathrm{ns}}$ & $2091.471^{\mathrm{ns}}$ & $2787.541^{* *}$ & $14708.122^{\mathrm{ns}}$ \\
\hline Error b & 12 & 742.543 & 64.848 & 922.474 & 2060.920 & 20744.415 \\
\hline Genotypes & 11 & $640247.613^{* *}$ & $189749.713^{* *}$ & $3644030.377^{* *}$ & * $939295.339^{* *}$ & $1912811.473^{* *}$ \\
\hline Genotypes $\times$ year & 11 & $9226.510^{*}$ & $573.303^{* *}$ & $9172.964^{* *}$ & $1244.822^{* *}$ & $7975.587^{\mathrm{ns}}$ \\
\hline $\begin{array}{l}\text { Irrigation regimes } \times \\
\text { genotypes }\end{array}$ & 33 & $9611.064^{* *}$ & $3315.760^{* *}$ & $1182.420^{\mathrm{ns}}$ & $4301.277^{* *}$ & $11582.615^{*}$ \\
\hline $\begin{array}{l}\text { Irrigation regimes } \times \text { year } \\
\times \text { genotypes }\end{array}$ & 33 & $6804.544^{*}$ & $307.815^{* *}$ & $3518.685^{*}$ & $658.234^{* *}$ & $11618.506^{*}$ \\
\hline Error c & 176 & 3984.748 & 161.880 & 2198.123 & 366.246 & 6796.868 \\
\hline C.V (\%) & - & 5.407 & 4.734 & 4.777 & 5.305 & 8.830 \\
\hline
\end{tabular}

ns, ${ }^{*}$ and ${ }^{* *}$ : Nonsignificant, and significant at 5 and $1 \%$ level of probability, respectively 
According to mean comparison, the highest and lowest anther lengths were related to the third (5-day interval) and the first (1-day interval) irrigation regimes, respectively (Table 4). The interaction between the two factors is shown in Figure 1 ( $a$ and $b$ ), which genotypes reaction was entirely dependent on irrigation regimes so that genotype IR 78908-193-B-3-B with high tolerance to drought had the longest anther in all irrigation regimes due to the genetic reasons, and the lowest length $(1448.271 \mu \mathrm{m})$ was seen in the second irrigation regime. In other irrigation regimes, anther length of this genotype was in one statistic class. The lowest length of anther $(930.056 \mu \mathrm{m})$ was seen in Tarom in the first irrigation regime (1-day interval), which had the least drought tolerance among the studied genotypes. It seems that based on genotypes resistance to drought, reduced anther length with increased contact with pollen and prevention of wasting pollen fertility could increase fertility and grain yield. Thus, increasing performance of genotype IR 78908-193-B-3-B in 3- day interval irrigation and Tarom in 1- day interval irrigation can be due to the reduced length of anthers, increased fertility efficiency and trapping pollens (Table 5).

Table 4. Mean comparison of floret anatomical characteristics

\begin{tabular}{|c|c|c|c|c|c|}
\hline Treatments & $\begin{array}{c}\text { Anther length } \\
(\mu \mathrm{m})\end{array}$ & $\begin{array}{c}\text { Anther width } \\
(\mu \mathrm{m})\end{array}$ & $\begin{array}{c}\text { Stigma length } \\
(\mu \mathrm{m})\end{array}$ & $\begin{array}{c}\text { Style length } \\
(\mu \mathrm{m})\end{array}$ & $\begin{array}{c}\text { Pollen area } \\
\left(\mu \mathrm{m}^{2}\right)\end{array}$ \\
\hline \multicolumn{6}{|l|}{ Irrigation regimes } \\
\hline I1 & $1134.149 \mathrm{~d}$ & $277.672 \mathrm{a}$ & $970.172 \mathrm{~b}$ & $364.426 \mathrm{a}$ & $955.499 \mathrm{ab}$ \\
\hline $\mathrm{I} 2$ & $1157.250 \mathrm{c}$ & $279.879 \mathrm{a}$ & $974.414 \mathrm{~b}$ & $370.238 \mathrm{a}$ & $986.675 \mathrm{a}$ \\
\hline I3 & $1202.256 \mathrm{a}$ & $277.406 \mathrm{a}$ & $989.771 \mathrm{a}$ & $355.507 \mathrm{a}$ & $922.476 \mathrm{~b}$ \\
\hline $\mathrm{I} 4$ & $1175.717 \mathrm{~b}$ & $239.998 \mathrm{~b}$ & $991.428 \mathrm{a}$ & $352.687 \mathrm{~b}$ & $869.657 \mathrm{c}$ \\
\hline \multicolumn{6}{|l|}{ Genotypes } \\
\hline VANDANA & $1110.980 \mathrm{f}$ & $318.097 \mathrm{c}$ & $567.976 \mathrm{~g}$ & $490.643 \mathrm{c}$ & $1137.886 \mathrm{~b}$ \\
\hline IR 78908-193-B-3-B & $1481.819 \mathrm{a}$ & $368.137 \mathrm{~b}$ & $1360.728 \mathrm{~b}$ & $837.301 \mathrm{a}$ & $765.051 \mathrm{e}$ \\
\hline IR 81429-B-31 & $1373.085 \mathrm{~b}$ & $230.297 \mathrm{e}$ & $584.722 \mathrm{fg}$ & $239.530 \mathrm{~h}$ & $1255.353 \mathrm{a}$ \\
\hline IR 78875-176-B-1-B & $1123.656 \mathrm{f}$ & $168.841 \mathrm{i}$ & $1668.796 \mathrm{a}$ & $641.445 \mathrm{~b}$ & $661.674 \mathrm{f}$ \\
\hline IR 79971-B-202-2-4 & $1224.765 \mathrm{~d}$ & $198.580 \mathrm{~g}$ & $791.294 \mathrm{e}$ & $240.386 \mathrm{~h}$ & $584.730 \mathrm{~g}$ \\
\hline IR 80508-B-194-4-B & $1172.364 \mathrm{e}$ & $312.091 \mathrm{c}$ & $782.144 \mathrm{e}$ & $315.958 \mathrm{e}$ & $1261.110 \mathrm{a}$ \\
\hline IR 80508-B-194-3-B & $979.791 \mathrm{i}$ & $465.234 \mathrm{a}$ & $1184.453 \mathrm{~d}$ & $173.422 \mathrm{i}$ & $1226.431 \mathrm{a}$ \\
\hline IR 79907-B-493-3-1 & $1229.204 \mathrm{~d}$ & $314.409 \mathrm{c}$ & $1287.965 \mathrm{c}$ & $267.249 \mathrm{f}$ & $1001.949 \mathrm{c}$ \\
\hline IR 81025-B-347-3 & $1062.733 \mathrm{~g}$ & $253.969 \mathrm{~d}$ & $1284.054 \mathrm{c}$ & $255.775 \mathrm{fg}$ & $1024.589 \mathrm{c}$ \\
\hline IR 81025-B-327-3 & $1020.734 \mathrm{~h}$ & $208.821 \mathrm{f}$ & $1173.084 \mathrm{~d}$ & $260.136 \mathrm{fg}$ & $985.301 \mathrm{c}$ \\
\hline NADA & $1297.232 \mathrm{c}$ & $208.613 \mathrm{f}$ & $605.581 \mathrm{f}$ & $353.342 \mathrm{~d}$ & $911.373 \mathrm{~d}$ \\
\hline TAROM & $931.753 \mathrm{j}$ & $177.778 \mathrm{~h}$ & $486.559 \mathrm{~h}$ & $253.385 \mathrm{~g}$ & $387.473 \mathrm{~h}$ \\
\hline
\end{tabular}

Means in each column, followed by at least one similar letter(s) are not significantly different at $5 \%$ probability level using Duncan's Multiple Range Test

I1, I2, I3 and I4 include irrigation regimes of 1, 3, 5 and 7 days, respectively 

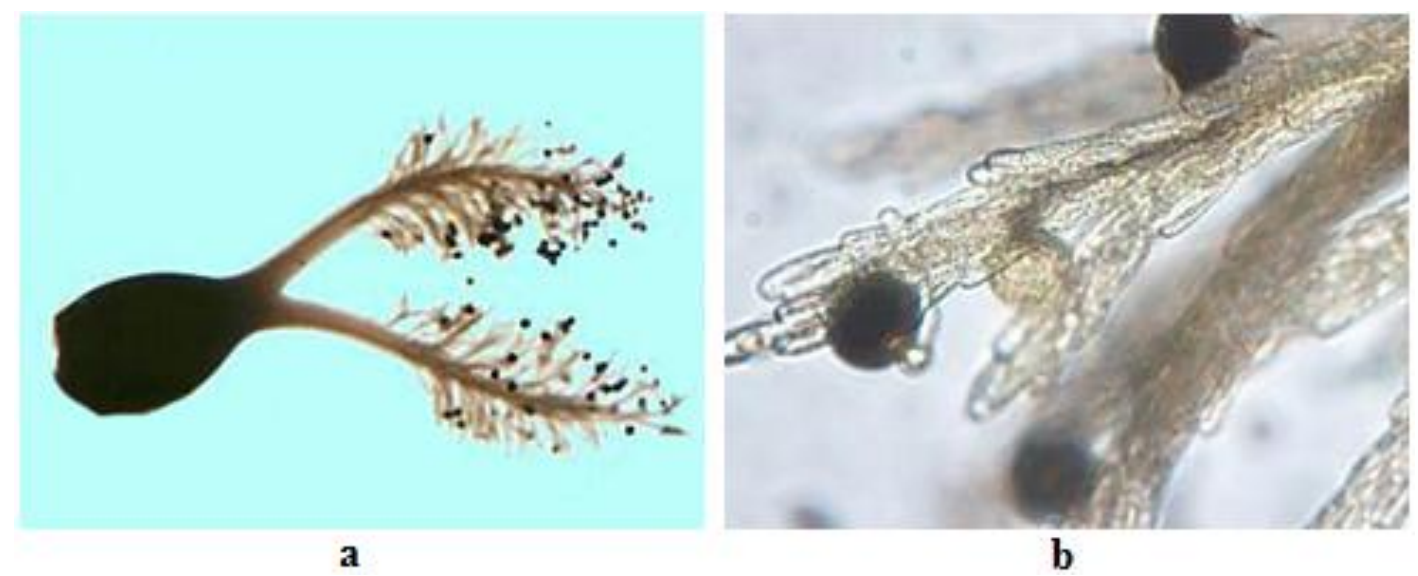

Figure 1. Floret anatomy; a: pollen received by the stigma; $b$ : pollen fertility

Table 5. Mean comparison of floret anatomical characteristics in study treatments

\begin{tabular}{|c|c|c|c|c|c|c|}
\hline \multicolumn{2}{|r|}{ Treatments } & \multirow[b]{2}{*}{$\begin{array}{c}\text { Anther length } \\
(\mu \mathrm{m})\end{array}$} & \multirow[b]{2}{*}{$\begin{array}{l}\text { Anther width } \\
\qquad(\mu \mathrm{m})\end{array}$} & \multirow[b]{2}{*}{$\begin{array}{c}\text { Stigma length } \\
(\mu \mathrm{m})\end{array}$} & \multirow[b]{2}{*}{$\begin{array}{c}\text { Style length } \\
(\mu \mathrm{m})\end{array}$} & \multirow[b]{2}{*}{$\begin{array}{c}\text { Pollen area } \\
\left(\mu \mathrm{m}^{2}\right)\end{array}$} \\
\hline 卷 & 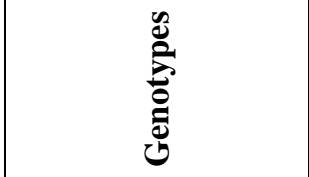 & & & & & \\
\hline \multirow{12}{*}{ I1 } & VANDANA & $1071.510 \mathrm{~h}-\mathrm{k}$ & $291.176 \mathrm{ij}$ & $559.159 \mathrm{gh}$ & $491.345 \mathrm{f}$ & $1184.520 \mathrm{a}-\mathrm{d}$ \\
\hline & IR 78908-193-B-3-B & $1489.175 \mathrm{a}$ & $390.067 \mathrm{e}$ & $1360.874 \mathrm{~b}$ & $853.066 \mathrm{ab}$ & $745.7071-p$ \\
\hline & IR 81429-B-31 & $1364.309 \mathrm{a}-\mathrm{d}$ & $220.771 \mathrm{~m}-\mathrm{p}$ & $580.830 \mathrm{gh}$ & $232.526 \mathrm{p}-\mathrm{t}$ & $1250.097 \mathrm{ab}$ \\
\hline & IR 78875-176-B-1-B & 1057.614 h-k & $160.507 \mathrm{~s}-\mathrm{u}$ & $1662.246 \mathrm{a}$ & $619.957 \mathrm{e}$ & $663.791 \mathrm{o}-\mathrm{q}$ \\
\hline & IR 79971-B-202-2-4 & $1179.800 \mathrm{f}-\mathrm{h}$ & $213.384 \mathrm{~m}-\mathrm{q}$ & $791.225 \mathrm{f}$ & $229.144 \mathrm{p}-\mathrm{t}$ & $582.333 \mathrm{qr}$ \\
\hline & IR 80508-B-194-4-B & $1143.127 \mathrm{f}-\mathrm{i}$ & $332.787 \mathrm{f}-\mathrm{h}$ & $756.276 \mathrm{f}$ & $343.755 \mathrm{k}-\mathrm{j}$ & $1311.327 \mathrm{a}$ \\
\hline & IR 80508-B-194-3-B & $956.229 \mathrm{kl}$ & $493.116 \mathrm{a}$ & $1158.657 \mathrm{e}$ & $201.201 \mathrm{tu}$ & $1280.356 \mathrm{ab}$ \\
\hline & IR 79907-B-493-3-1 & $1174.112 \mathrm{f}-\mathrm{h}$ & $334.953 \mathrm{f}-\mathrm{h}$ & $1277.590 \mathrm{~b}-\mathrm{e}$ & $289.868 \mathrm{k}-\mathrm{m}$ & $1051.923 \mathrm{~d}-\mathrm{h}$ \\
\hline & IR 81025-B-347-3 & $1011.152 \mathrm{i}-1$ & $290.735 \mathrm{ij}$ & 1251.706 b-e & 271.977 k-p & $1100.482 \mathrm{c}-\mathrm{g}$ \\
\hline & IR $81025-B-327-3$ & $999.617 \mathrm{j}-1$ & 199.265 n-r & $1172.208 \mathrm{c}-\mathrm{e}$ & $251.145 \mathrm{~m}-\mathrm{s}$ & $997.017 \mathrm{f}-\mathrm{i}$ \\
\hline & NADA & $1260.090 \mathrm{c}-\mathrm{f}$ & 209.217 n-r & $603.849 \mathrm{~g}$ & $352.276 \mathrm{~g}-\mathrm{i}$ & $878.155 \mathrm{i}-1$ \\
\hline & TAROM & 903.0561 & 196.089 o-r & $467.445 \mathrm{~h}$ & $236.851 \mathrm{o}-\mathrm{t}$ & $420.279 \mathrm{st}$ \\
\hline \multirow{9}{*}{$\mathrm{I} 2$} & VANDANA & $1066.018 \mathrm{~h}-\mathrm{k}$ & $340.933 \mathrm{fg}$ & $552.512 \mathrm{gh}$ & $484.741 \mathrm{f}$ & $1235.021 \mathrm{a}-\mathrm{c}$ \\
\hline & IR 78908-193-B-3-B & $1448.271 \mathrm{ab}$ & $397.428 \mathrm{de}$ & $1354.867 \mathrm{~b}$ & $812.564 \mathrm{c}$ & $819.228 \mathrm{k}-\mathrm{n}$ \\
\hline & IR 81429-B-31 & 1341.588 b-d & $229.7251-0$ & $589.862 \mathrm{gh}$ & $213.975 \mathrm{r}-\mathrm{u}$ & $1287.564 \mathrm{ab}$ \\
\hline & IR 78875-176-B-1-B & $1062.295 \mathrm{~h}-\mathrm{k}$ & $175.526 \mathrm{r}-\mathrm{u}$ & $1620.856 \mathrm{a}$ & $626.857 \mathrm{e}$ & $689.605 n-q$ \\
\hline & IR 79971-B-202-2-4 & 1190.020 e-h & $210.576 \mathrm{~m}-\mathrm{r}$ & $775.121 \mathrm{f}$ & $236.709 \mathrm{o}-\mathrm{t}$ & $758.3821-\mathrm{p}$ \\
\hline & IR 80508-B-194-4-B & $1159.017 \mathrm{f}-\mathrm{h}$ & $314.128 \mathrm{~g}-\mathrm{i}$ & $770.769 \mathrm{f}$ & $311.118 \mathrm{i}-\mathrm{k}$ & $1287.022 \mathrm{ab}$ \\
\hline & IR 80508-B-194-3-B & $981.252 \mathrm{j}-1$ & $483.203 \mathrm{ab}$ & $1183.394 \mathrm{c}-\mathrm{e}$ & $185.586 \mathrm{uv}$ & $1251.348 \mathrm{ab}$ \\
\hline & IR 79907-B-493-3-1 & $1285.357 \mathrm{c}-\mathrm{f}$ & $313.941 \mathrm{~g}-\mathrm{i}$ & $1278.831 \mathrm{~b}-\mathrm{e}$ & 273.749 k-p & $1013.444 \mathrm{f}-\mathrm{i}$ \\
\hline & IR $81025-B-347-3$ & $1078.018 \mathrm{~h}-\mathrm{k}$ & $258.708 \mathrm{j}-1$ & 1291.534 b-d & $279.273 \mathrm{k}-\mathrm{o}$ & $1056.018 \mathrm{~d}-\mathrm{h}$ \\
\hline
\end{tabular}




\begin{tabular}{|c|c|c|c|c|c|c|}
\hline & $\begin{array}{c}\text { IR 81025-B-327-3 } \\
\text { NADA } \\
\text { TAROM }\end{array}$ & $\begin{array}{c}995.436 \mathrm{j}-\mathrm{l} \\
1323.895 \mathrm{~b}-\mathrm{e} \\
955.839 \mathrm{kl}\end{array}$ & $\begin{array}{l}232.734 \text { l-n } \\
209.957 \text { m-r } \\
191.689 \text { p-s }\end{array}$ & $\begin{array}{l}1191.761 \mathrm{c}-\mathrm{e} \\
593.706 \mathrm{gh} \\
489.759 \mathrm{gh}\end{array}$ & $\begin{array}{c}288.035 \mathrm{k}-\mathrm{n} \\
390.169 \mathrm{~g} \\
340.073 \mathrm{~h}-\mathrm{j}\end{array}$ & $\begin{array}{c}1051.923 \mathrm{~d}-\mathrm{h} \\
987.433 \mathrm{f}-\mathrm{i} \\
403.112 \mathrm{st}\end{array}$ \\
\hline \multirow{12}{*}{ I3 } & VANDANA & $1156.019 \mathrm{f}-\mathrm{h}$ & $351.963 \mathrm{f}$ & $578.583 \mathrm{gh}$ & $496.488 \mathrm{f}$ & $1027.005 \mathrm{e}-\mathrm{h}$ \\
\hline & IR 78908-193-B-3-B & $1496.416 \mathrm{a}$ & $426.277 \mathrm{~cd}$ & $1365.090 \mathrm{~b}$ & $815.574 \mathrm{bc}$ & $792.2201-0$ \\
\hline & IR 81429-B-31 & $1396.225 \mathrm{a}-\mathrm{c}$ & $256.923 \mathrm{kl}$ & $585.102 \mathrm{gh}$ & $258.930 \mathrm{~m}-\mathrm{r}$ & $1277.021 \mathrm{ab}$ \\
\hline & IR 78875-176-B-1-B & $1183.192 \mathrm{f}-\mathrm{h}$ & $186.852 \mathrm{p}-\mathrm{s}$ & $1694.725 \mathrm{a}$ & $640.921 \mathrm{de}$ & $682.299 \mathrm{n}-\mathrm{q}$ \\
\hline & IR 79971-B-202-2-4 & $1258.220 \mathrm{c}-\mathrm{f}$ & $189.865 \mathrm{p}-\mathrm{s}$ & $798.640 \mathrm{f}$ & $251.689 \mathrm{~m}-\mathrm{s}$ & $511.105 \mathrm{rs}$ \\
\hline & IR 80508-B-194-4-B & $1200.053 \mathrm{e}-\mathrm{h}$ & $304.092 \mathrm{hi}$ & $794.855 \mathrm{f}$ & $303.911 \mathrm{j}-1$ & $1243.091 \mathrm{a}-\mathrm{c}$ \\
\hline & IR $80508-B-194-3-B$ & $992.817 \mathrm{j}-1$ & $455.074 \mathrm{bc}$ & $1193.440 \mathrm{c}-\mathrm{e}$ & $156.494 \mathrm{v}$ & $1215.020 \mathrm{a}-\mathrm{c}$ \\
\hline & IR 79907-B-493-3-1 & $1280.022 \mathrm{c}-\mathrm{f}$ & $309.848 \mathrm{~g}-\mathrm{i}$ & $1299.556 \mathrm{bc}$ & $265.7271-q$ & $989.275 \mathrm{f}-\mathrm{i}$ \\
\hline & IR $81025-B-347-3$ & $1151.320 \mathrm{f}-\mathrm{h}$ & $244.733 \mathrm{~lm}$ & $1294.880 \mathrm{bc}$ & $236.851 \mathrm{o}-\mathrm{t}$ & $975.856 \mathrm{f}-\mathrm{j}$ \\
\hline & IR $81025-B-327-3$ & $985.865 \mathrm{j}-1$ & $211.761 \mathrm{~m}-\mathrm{q}$ & $1165.186 \mathrm{de}$ & $256.810 \mathrm{~m}-\mathrm{s}$ & $1013.203 \mathrm{f}-\mathrm{i}$ \\
\hline & NADA & $1363.598 \mathrm{a}-\mathrm{d}$ & $213.674 \mathrm{~m}-\mathrm{q}$ & $609.925 \mathrm{~g}$ & $357.070 \mathrm{gh}$ & 942.260 h-k \\
\hline & TAROM & $963.322 \mathrm{j}-1$ & $177.811 \mathrm{q}-\mathrm{u}$ & $497.267 \mathrm{gh}$ & $225.617 \mathrm{q}-\mathrm{u}$ & $401.352 \mathrm{st}$ \\
\hline \multirow{12}{*}{ I4 } & VANDANA & $1150.373 \mathrm{f}-\mathrm{h}$ & $288.314 \mathrm{i}-\mathrm{k}$ & $581.651 \mathrm{gh}$ & $490.000 \mathrm{f}$ & $1105.000 \mathrm{c}-\mathrm{f}$ \\
\hline & IR 78908-193-B-3-B & $1493.415 \mathrm{a}$ & $258.775 \mathrm{j}-1$ & $1362.081 \mathrm{~b}$ & $868.000 \mathrm{a}$ & $703.048 \mathrm{~m}-\mathrm{q}$ \\
\hline & IR 81429-B-31 & $1390.220 \mathrm{a}-\mathrm{c}$ & $213.768 \mathrm{~m}-\mathrm{q}$ & $583.095 \mathrm{gh}$ & $252.687 \mathrm{~m}-\mathrm{s}$ & $1206.728 \mathrm{a}-\mathrm{c}$ \\
\hline & IR 78875-176-B-1-B & $1191.522 \mathrm{e}-\mathrm{h}$ & $152.481 \mathrm{tu}$ & $1697.357 \mathrm{a}$ & $678.046 \mathrm{~d}$ & $611.000 \mathrm{p}-\mathrm{r}$ \\
\hline & IR 79971-B-202-2-4 & $1271.021 \mathrm{c}-\mathrm{f}$ & $180.494 \mathrm{q}-\mathrm{t}$ & $800.190 \mathrm{f}$ & $244.000 \mathrm{n}-\mathrm{t}$ & $487.101 \mathrm{rs}$ \\
\hline & IR 80508-B-194-4-B & 1187.260 e-h & $297.355 \mathrm{i}$ & $806.677 \mathrm{f}$ & $305.047 \mathrm{j}-1$ & $1203.000 \mathrm{a}-\mathrm{c}$ \\
\hline & IR 80508-B-194-3-B & $988.868 \mathrm{j}-1$ & $429.543 \mathrm{c}$ & $1202.319 \mathrm{c}-\mathrm{e}$ & $150.409 \mathrm{v}$ & $1159.000 \mathrm{~b}-\mathrm{e}$ \\
\hline & IR 79907-B-493-3-1 & $1177.327 \mathrm{f}-\mathrm{h}$ & $298.896 \mathrm{i}$ & $1295.883 \mathrm{bc}$ & 239.652 o-t & $953.155 \mathrm{~g}-\mathrm{k}$ \\
\hline & IR $81025-B-347-3$ & $1010.443 \mathrm{i}-1$ & $221.700 \mathrm{~m}-\mathrm{p}$ & $1298.097 \mathrm{bc}$ & $235.000 \mathrm{o}-\mathrm{t}$ & $966.000 \mathrm{f}-\mathrm{j}$ \\
\hline & IR $81025-B-327-3$ & $1102.019 \mathrm{~g}-\mathrm{j}$ & $191.524 \mathrm{p}-\mathrm{s}$ & $1163.183 \mathrm{de}$ & $244.553 \mathrm{n}-\mathrm{t}$ & 879.060 i-1 \\
\hline & NADA & $1241.345 \mathrm{~d}-\mathrm{g}$ & 201.604 n-r & $614.842 \mathrm{~g}$ & $313.854 \mathrm{i}-\mathrm{k}$ & $837.644 \mathrm{j}-\mathrm{m}$ \\
\hline & TAROM & 904.7941 & $145.523 \mathrm{u}$ & $491.767 \mathrm{gh}$ & $211.000 \mathrm{~s}-\mathrm{u}$ & $325.150 \mathrm{t}$ \\
\hline
\end{tabular}

Means in each column, followed by at least one similar letter(s) are not significantly different at $5 \%$ probability level using Duncan's Multiple Range Test

I1, I2, I3 and I4 include irrigation regimes of 1, 3, 5 and 7 days, respectively

Due to the fact that starch degradation and the availability of non-structural carbohydrates are essential for formation of anther wall and elongation together with the generative (producing pollen), it seems that depending on the irrigation regime the relative contribution of these carbohydrates is different in formation of anther parts. The results did not correspond to Suzuki (1981) on larger anthers had more pollens that can compensate the reduction of number of germinated pollen and thereby increase the tolerance to thermal stress, because in addition to pollen number, their size and the water potential of each pollen to create pressure for anther opening and pollen releasing are also factors for increasing fertility. 
Correlation coefficients results showed that length negatively correlated with yield (0.012), which can be due to the longer length of anther for transferring pollen from the anther to the stigma and this corresponded to other studies (Arvin and Vafabakhsh, 2016; Akbari et al., 2016) on high effect of increased fertility on grain yield (Table 6).

Table 6. Correlation coefficients between grain yield and traits related to floret anatomy of rice genotypes

\begin{tabular}{c|c|c|c|c|c|c}
\hline & 1 & 2 & 3 & 4 & 5 & 6 \\
\hline 1-grain yield & 1 & -0.012 & 0.027 & $0.139^{*}$ & -0.067 & 0.038 \\
2-anther length & & 1 & $0.141^{*}$ & 0.095 & $0.462^{* *}$ & $0.129^{*}$ \\
3-anther width & & & 1 & $0.224^{* *}$ & 0.093 & $0.545^{* *}$ \\
4-stigma length & & & & 1 & $0.404^{* *}$ & -0.019 \\
5-Style length & & & & & 1 & $-0.204^{* *}$ \\
6-pollen area & & & & & & 1 \\
\hline
\end{tabular}

${ }^{*}$ and ${ }^{* *}$ : Significant at $5 \%$ and $1 \%$ probability levels, respectively

\section{Anther width}

Results of combined analysis showed that differences between factors except for interaction between year and irrigation regimes (Table 3). According to mean comparison, anther width was in one level for three irrigation regimes (1-, 3- and 5-day interval) shown in Figure 1 ( $a$ and $b$ ), but significant decrease in anthers width was seen in the fourth irrigation regime ( 7 day interval) due to the reduced nutrients transportation and lack of growth and this could be one of the reasons of grain yield reduction due to decreased diameter suitable for the pollen passage. Genotype IR 80508-B-194-3-B had the widest anther in all irrigation regimes, which the highest width $(493.116 \mu \mathrm{m})$ was seen in the first irrigation regime (1-day interval) and the lowest width was seen in the fourth irrigation regime (7-day interval) and the lowest width in this irrigation regime belonged to Tarom $(145.523 \mu \mathrm{m})$ (Fig. 1, Tables 4 and 5). Comparison of changes trends in fertility and anther width showed it was a slightly different trend or in other words, having the widest anther does not lead to higher fertility. Although it seems that wider and longer anthers have more potential for more pollens. The above results corresponded to those of Mamnan et al. (2009).

\section{Stigma length}

In this study it was found that the effect of years, genotypes and the interaction of years and genotypes were significant at $1 \%$ level and the effect of irrigation regimes and the interaction of years, irrigation regimes and genotypes were significant at $5 \%$ level but no significant difference was observed for other effects (Table 3). Mean comparisons showed that increasing irrigation interval had increased stigma length, so that the longest stigma $(991.428 \mu \mathrm{m})$ was observed in the fourth irrigation regime (7day interval) (Table 4). Due to the interaction of two factors, the maximum length of stigma was related to genotype IR 78875-176-B-1-B, which was in one statistical level in all irrigation regimes. The minimum length of stigma was related to Tarom, which reduction in irrigation intervals affected stigma length. The results indicated the 
presence of genetic differentiation between them and it can be concluded this difference was due to the plant internal and genetic factors that requires more attention to breeding and improvement of rice genotypes in order to optimize the length of stigma with anther length to enhance pollen contact and fertility and finally raising grain yield (Table 5). Comparing length of anther and stigma the fourth irrigation regime (7-day interval) suggested an almost same trend and other reasons were reduced nutrients absorption and as a result reduced anther growth. Irrigation regimes with longed anthers had longer stigmas. But the process was quite different among the genotypes and genotypes with longer anthers had shorter stigmas. The results regardless of water conditions can be due to stigmas' morphological differences in receiving and holding pollens. On the other hand, irrigation regimes with larger anthers and longer stigmas had more pollen, which was consistent with Suzuki (1981) on the correlations between the length of stigmas and pollen number. Relative comparison of anthers and stigmas in the fourth irrigation regime suggested a same trend between them and irrigation regimes with longer stigmas had longer anthers. However, this trend was not constant among genotypes and it seems this result is due to the difference between genotypes in terms of stigma morphological characteristics. The above results were consistent with Oyiga et al. (2010) (Figure 1).

Stigma length was positively correlated with grain yield $(0.139 *)$. It seems that increased length had caused less distance between stigma and anther and hence receiving more pollen, fertility and grain yield, which corresponded to (Oyiga et al., 2010) (Table 6).

\section{Style length}

The results showed that all factors were significantly different at $1 \%$ level (Table 3). The second irrigation regime (3-day interval) and the fourth irrigation regime (7-day interval) had the longest and shortest styles, respectively (Table 4). The interaction between genotype and irrigation regimes the differences were very diverse and resistance genotypes had longer styles. Unlike genotypes with less resistance, genotype IR 78908-193-B-3-B, which had the longest style in all irrigation regimes, had the longest style $(868 \mu \mathrm{m})$ in the fourth irrigation regime (7-day interval) and the shortest styles were seen in genotypes with lower resistance. Increasing the planting space affected the style length, so that genotype IR 80508-B-194-3-B had the shortest styles $(150.409 \mu \mathrm{m})$ in the fourth irrigation regime (7-day interval) (Table 5). Given that the time required for pollen tube to reach embryo sac is affected by the irrigation amount, the relative comparison of the length of style and stigma (Takeoka et al., 1992) showed that the style length in the fourth irrigation regime (7-day interval) was slightly higher than other irrigation regimes. The length of pollen tube was very short despite the fact that the lengths of anthers and stigma were high. With improving irrigation conditions in 3-day interval regime at the time of pollination and fertilization, the style length increased. Genotype IR 80508-B-194-3-B with shortest style had a good fertility rate. According to the results, it seems that in addition to anthers' size, the release of pollen and stigmas power to hold pollens, the role of style after the process of pollination is very important for fertilization and seed production. The results corresponded to (Oyiga et al., 2010) on increased length of style in favorable conditions (Figure 1).

Correlation coefficients showed this trait had a significant correlation with anthers length $(0.462 * *)$, stigmas length $(0.0404 * *)$ and pollen area $(-0.204 * *)$, which shows the positive and negative effects on these traits because of the increased length of these 
traits together led to perfect adjustment of female organs to get the pollen from the male organ. However, increased pollen area because of inverse relationship with increases style diameter can decline the transferring or accelerating of pollen transport to the ovary, and finally fertility and increased grain yield. Recent comments are consistent with others (Arvin and Vafabakhsh, 2016; Akbari et al., 2016) (Table 6).

\section{Pollen area}

Results of combined analysis showed that the effect of year, irrigation regimes and genotypes were significant at $1 \%$ level and the interaction of irrigation regimes and genotypes, year and irrigation regimes and genotypes were significant at 5\% level, but in other cases the differences were not observed (Table 3). The mean comparisons revealed that the highest and lowest pollen areas were seen in the second irrigation regime $(986.675 \mu \mathrm{m})$ and in the fourth irrigation regime $(869.657 \mu \mathrm{m})$, respectively (Table 4). The interaction between the two factors, genotype IR 80508-B-194-4-B with low resistance to drought had the highest pollen area in all irrigation regimes that decreased with increasing irrigation like other genotypes with low resistance, while increased pollen area was seen in genotypes with higher resistance in 3-day irrigation regime, which can be one of the main reasons for increasing grain yield due to having more nutrients energy in larger pollens and more strength to reach the ovary and pollen fertility (Table 5). Comparing the size and number of pollens in different planting regimes confirms that the second irrigation regime (3-day interval) had led to larger but less pollens. The pollen fertility can be showed based on the interaction between the amount of starch in pollen and iodide compound, which the pollen staining rate was very high in the second and third irrigation regimes and pollen were mainly globular with dark color. However, the pollen staining rate was low in the fourth irrigation regime (7-day interval) and a lot of damaged pollens with abnormal shape were observed. Recent results consistent with Sing et al. (2005). In addition, these results consistent with Erie classification system (Anonymous, 1982) that showed pollens were globular with dark color.

According to Table 6, the pollen area had a positive and significant correlation with male organ in terms of the same influence on all male organs in one direction and also with the style length that had to travel a long distance to reach the ovary as well as the reduction of large pollens entry to the longer styles with reduced diameter are the reasons for lack of entry and thus fertility and grain yield, a significant negative correlation was seen $(-0.204 * *)$. The results consistent with other studies (Arvin and Vafabakhsh, 2016; Akbari et al., 2016).

\section{Central cylindrical area of roots}

In terms of the characteristics associated with root, it can be stated that the desirable characteristics of a root system can change with different soil and climatic conditions (Moshafaghi et al., 2014). In this study it was found that the effect of year, genotypes and irrigation regimes and interaction between year and genotypes were significant at $1 \%$ and the simultaneous effect of three year, irrigation regimes and genotypes was significantly different at 5\% (Table 7). Increasing irrigation intervals resulted from increasing drought had reduced the central cylindrical area due to loss of vascular bundles area inside it due to better water conservation and efficiency (Table 8). 
Table 7. Combined analysis results of root anatomy, yield and yield components in study treatments

\begin{tabular}{|c|c|c|c|c|c|c|c|}
\hline \multirow[b]{2}{*}{ S.O.V } & \multirow[b]{2}{*}{ Df } & \multicolumn{6}{|c|}{ MS } \\
\hline & & $\begin{array}{c}\text { Central } \\
\text { cylindrical area }\end{array}$ & Xylem area & $\begin{array}{c}\text { Weight } \\
\text { of one } \\
\text { thousand } \\
\text { seeds }\end{array}$ & $\begin{array}{l}\text { Fertility } \\
\text { rate }\end{array}$ & $\begin{array}{l}\text { Dry matter } \\
\text { yield }\end{array}$ & Grain yield \\
\hline Year & 1 & $532301934.871^{* *}$ & $649802.910^{* *}$ & $10.975^{* *}$ & $450.530^{*}$ & $25853424.092^{* *}$ & $13560464.565^{* *}$ \\
\hline $\begin{array}{l}\text { Rep. } \\
\text { (year) } \\
\text { (error a) }\end{array}$ & 4 & 217099458.739 & 370515.839 & 0.038 & 522.297 & 2561996.467 & 989008.720 \\
\hline $\begin{array}{l}\text { Irrigation } \\
\text { regimes }\end{array}$ & 3 & $121782699.834^{* *}$ & $782288.739^{* *}$ & $16.219^{* *}$ & $10234.224^{* *}$ & $145357543.359^{* *}$ & 39098649.286 \\
\hline $\begin{array}{c}\text { Irrigation } \\
\text { regimes } \times \\
\text { year }\end{array}$ & 3 & $1895166.349^{\mathrm{ns}}$ & $859.876^{\mathrm{ns}}$ & $0.309^{\mathrm{ns}}$ & $60.241^{\mathrm{ns}}$ & $2388814.301^{*}$ & $2585374.714^{* *}$ \\
\hline Error b & 12 & 702342.089 & 7930.907 & 0.683 & 135.897 & 1492151.462 & 753853.818 \\
\hline Genotypes & 11 & $3993166519.985^{* * *}$ & $2968066.061^{* * *}$ & $41.780^{* *}$ & $6099.922^{* *}$ & $43916270.470^{* *}$ & $9638043.784^{* *}$ \\
\hline $\begin{array}{c}\text { Genotypes } \\
\times \text { year }\end{array}$ & 11 & $13514833.748^{* *}$ & $9317.783^{\text {ns }}$ & $0.366^{* *}$ & $21.869^{\mathrm{ns}}$ & $447358.432^{\mathrm{ns}}$ & $597461.724^{\mathrm{ns}}$ \\
\hline $\begin{array}{l}\text { Irrigation } \\
\text { regimes } \times \\
\text { genotypes }\end{array}$ & 33 & $2457257.675^{\mathrm{ns}}$ & $60467.631^{* *}$ & $1.662^{* *}$ & $1028.451^{* * *}$ & $8971677.302^{* *}$ & $3136384.190^{* *}$ \\
\hline $\begin{array}{c}\text { Irrigation } \\
\text { regimes } \times \\
\text { year } \times \\
\text { genotypes }\end{array}$ & 33 & $3617810.849^{*}$ & $10606.808^{\mathrm{ns}}$ & $0.402^{* *}$ & $10.192^{\mathrm{ns}}$ & $638523.996^{\mathrm{ns}}$ & $199931.307^{\mathrm{ns}}$ \\
\hline Error c & 176 & 2198614.595 & 10228.635 & 0.463 & 66.664 & 735416.732 & 432662.206 \\
\hline C.V (\%) & - & 4.976 & 11.700 & 3.412 & 12.223 & 6.726 & 15.39 \\
\hline
\end{tabular}

\footnotetext{
ns,${ }^{*}$ and ${ }^{* *}$ : Nonsignificant, and significant at 5 and $1 \%$ level of probability, respectively
} 
Table 8. Mean comparison of two years related to the anatomy of root, yield and yield components

\begin{tabular}{|c|c|c|c|c|c|c|}
\hline Treatments & $\begin{array}{c}\text { Central } \\
\text { cylindrical } \\
\text { area }\left(\mu \mathrm{m}^{2}\right)\end{array}$ & $\begin{array}{c}\text { Xylem area } \\
\left(\mu \mathrm{m}^{2}\right)\end{array}$ & $\begin{array}{l}\text { Weight of } \\
\text { one } \\
\text { thousand } \\
\text { seeds (g) }\end{array}$ & $\begin{array}{l}\text { Fertility } \\
\text { rate }(\%)\end{array}$ & $\begin{array}{c}\text { Dry matter } \\
\text { per hectare } \\
\quad(\mathbf{k g} / \mathrm{h})\end{array}$ & $\begin{array}{l}\text { Grain } \\
\text { yield } \\
(\mathrm{kg} / \mathrm{h})\end{array}$ \\
\hline \multicolumn{7}{|l|}{ Irrigation regimes } \\
\hline I1 & $31077.159 \mathrm{a}$ & $985.616 \mathrm{a}$ & $19.787 \mathrm{~b}$ & $78.882 \mathrm{a}$ & $12819.270 \mathrm{c}$ & $4100.79 \mathrm{c}$ \\
\hline $\mathrm{I} 2$ & $30642.669 \mathrm{~b}$ & $909.092 \mathrm{~b}$ & $20.394 \mathrm{a}$ & $73.340 \mathrm{~b}$ & $14049.324 \mathrm{a}$ & $5094.31 \mathrm{a}$ \\
\hline I3 & $29185.438 \mathrm{c}$ & $814.103 \mathrm{c}$ & $20.290 \mathrm{a}$ & $63.125 \mathrm{c}$ & $13374.369 \mathrm{~b}$ & $4548.26 \mathrm{~b}$ \\
\hline I4 & $28265.208 \mathrm{~d}$ & $748.750 \mathrm{~d}$ & $19.369 \mathrm{c}$ & $51.828 \mathrm{~d}$ & $10756.589 \mathrm{~d}$ & $3351.51 \mathrm{~d}$ \\
\hline \multicolumn{7}{|l|}{ Genotypes } \\
\hline VANDANA & $23924.493 \mathrm{~h}$ & $945.349 \mathrm{~d}$ & $20.644 \mathrm{bc}$ & $54.056 \mathrm{e}$ & $11177.049 \mathrm{e}$ & $3541.29 \mathrm{de}$ \\
\hline IR 78908-193-B-3-B & $18564.500 \mathrm{k}$ & $425.653 \mathrm{~h}$ & 19.783 ef & $84.030 \mathrm{ab}$ & $13276.174 \mathrm{bc}$ & $4303.04 \mathrm{~b}$ \\
\hline IR 81429-B-31 & $31880.354 \mathrm{~d}$ & $515.497 \mathrm{~g}$ & $19.484 \mathrm{fg}$ & $80.472 \mathrm{~b}$ & $15625.334 \mathrm{a}$ & $5025.67 \mathrm{a}$ \\
\hline IR 78875-176-B-1-B & $24824.404 \mathrm{~g}$ & 840.640 e & $20.048 \mathrm{de}$ & $86.172 \mathrm{a}$ & $12940.651 \mathrm{c}$ & $4091.79 \mathrm{bc}$ \\
\hline IR 79971-B-202-2-4 & $37201.567 \mathrm{c}$ & $1524.386 \mathrm{a}$ & $21.158 \mathrm{a}$ & $59.944 \mathrm{~d}$ & $13040.823 \mathrm{c}$ & $3806.83 \mathrm{~cd}$ \\
\hline IR 80508-B-194-4-B & $22239.397 \mathrm{i}$ & 848.389 e & $20.304 \mathrm{~cd}$ & $52.742 \mathrm{e}$ & $11443.065 \mathrm{e}$ & $3528.29 \mathrm{de}$ \\
\hline IR 80508-B-194-3-B & $48706.175 \mathrm{~b}$ & $1031.046 \mathrm{c}$ & $20.908 \mathrm{ab}$ & $55.969 \mathrm{de}$ & $12069.889 \mathrm{~d}$ & $4030.50 \mathrm{bc}$ \\
\hline IR 79907-B-493-3-1 & $21168.804 \mathrm{j}$ & $935.663 \mathrm{~d}$ & $20.542 \mathrm{bc}$ & $36.088 \mathrm{f}$ & $12306.970 \mathrm{~d}$ & $4843.87 \mathrm{a}$ \\
\hline IR 81025-B-347-3 & $58351.239 \mathrm{a}$ & $1450.986 \mathrm{~b}$ & $16.304 \mathrm{~h}$ & $69.085 \mathrm{c}$ & $13413.078 \mathrm{bc}$ & $4899.18 \mathrm{a}$ \\
\hline IR $81025-B-327-3$ & $29211.016 \mathrm{e}$ & $710.427 \mathrm{f}$ & $20.034 \mathrm{de}$ & $60.390 \mathrm{~d}$ & $13326.433 \mathrm{bc}$ & $5085.33 \mathrm{a}$ \\
\hline NADA & $28337.155 \mathrm{f}$ & $698.655 \mathrm{f}$ & $21.198 \mathrm{a}$ & $82.497 \mathrm{ab}$ & $10573.764 \mathrm{f}$ & $3362.21 \mathrm{e}$ \\
\hline TAROM & 13102.3201 & $445.993 \mathrm{~h}$ & $19.112 \mathrm{~g}$ & $80.082 \mathrm{~b}$ & $13805.428 \mathrm{~b}$ & $4766.62 \mathrm{a}$ \\
\hline
\end{tabular}

Means in each column, followed by at least one similar letter(s) are not significantly different at $5 \%$ probability level using Duncan's Multiple Range Test

I1, I2, I3 and I4 include irrigation regimes of 1, 3, 5 and 7 days, respectively

Further investigation on the interaction of irrigation regimes and genotype (Table 9) showed that genotype IR 81025-B-347-3 could achieve the highest central cylindrical area in all irrigation regimes due to genetic reasons; while, Tarom had the lowest central cylinder area in all irrigation regimes and like the previous genotype was in one statistical level in all irrigation regimes. So, in addition to environmental conditions, it can be concluded that the reason of differences between genotypes can be related to internal factors and genetics of studied rice genotypes, which did not correspond to other studies (Akbari et al., 2010; Sadat-jamali et al., 2014) reported that genotypes with less resistance had the lowest central cylindrical area and genotypes with greater resistance had the highest one. Because in the current study, the genotype with least 
resistance had the lowest central cylinder area but another genotype (IR 81025-B-347-3) with low resistance had the highest pollen area $\left(58351.239 \mu \mathrm{m}^{2}\right)$.

Table 9. Mean comparison of two years related to the anatomy of root, yield and yield components in study treatments

\begin{tabular}{|c|c|c|c|c|c|c|c|}
\hline & Treatments & & & & & & \\
\hline . & : & $\begin{array}{c}\text { cylindrical } \\
\text { area } \\
\left(\mu \mathrm{m}^{2}\right)\end{array}$ & $\begin{array}{c}\text { Xylem area } \\
\left(\mu \mathrm{m}^{2}\right)\end{array}$ & $\begin{array}{c}\text { one thousand } \\
\text { seeds } \\
\text { (g) }\end{array}$ & $\begin{array}{c}\text { Fertility } \\
\text { rate } \\
(\%)\end{array}$ & $\begin{array}{c}\text { Dry matter per } \\
\text { hectare } \\
(\mathrm{kg} / \mathrm{h})\end{array}$ & $\begin{array}{c}\text { Grain yield } \\
(\mathrm{kg} / \mathrm{h})\end{array}$ \\
\hline & VANDANA & $25362.1121-p$ & $1069.939 \mathrm{e}-\mathrm{g}$ & $20.558 \mathrm{~b}-\mathrm{i}$ & $69.779 \mathrm{j}-\mathrm{m}$ & $10595.500 \mathrm{p}-\mathrm{u}$ & $2332.10 x y$ \\
\hline & IR 78908-193-B-3-B & $20033.825 \mathrm{r}-\mathrm{t}$ & $470.008 \mathrm{t}-\mathrm{v}$ & 18.756 no & $95.933 \mathrm{ab}$ & $15405.833 b c$ & $4038.01 \mathrm{j}-\mathrm{t}$ \\
\hline & IR 81429-B-31 & 34068.070 e-g & $558.905 \mathrm{r}-\mathrm{v}$ & 18.609 no & 84.707 c-h & $15549.234 \mathrm{bc}$ & $4551.67 \mathrm{~d}-\mathrm{n}$ \\
\hline & IR 78875-176-B-1-B & $25214.3231-p$ & $911.400 \mathrm{~g}-\mathrm{n}$ & $20.221 \mathrm{e}-\mathrm{j}$ & $78.460 \mathrm{f}-\mathrm{j}$ & 13769.404 e-h & $2949.50 u-x$ \\
\hline & IR 79971-B-202-2-4 & $38285.522 \mathrm{~d}$ & $1901.032 \mathrm{a}$ & $21.055 \mathrm{a}-\mathrm{g}$ & 91.772 a-e & 11846.333 j-p & $3541.83 \mathrm{o}-\mathrm{w}$ \\
\hline & IR 80508-B-194-4-B & 22871.524 o-r & $904.501 \mathrm{~g}-\mathrm{n}$ & $20.609 \mathrm{~b}-\mathrm{i}$ & $79.856 \mathrm{f}-\mathrm{j}$ & $12518.579 \mathrm{i}-1$ & $4487.50 \mathrm{f}-\mathrm{p}$ \\
\hline & IR 80508-B-194-3-B & $50647.838 \mathrm{~b}$ & 1133.497 d-f & $20.422 \mathrm{e}-\mathrm{i}$ & $75.152 \mathrm{~g}-\mathrm{k}$ & $11558.119 \mathrm{k}-\mathrm{r}$ & 3559.83 n-w \\
\hline & IR 79907-B-493-3-1 & 22067.025 p-r & $999.127 \mathrm{f}-\mathrm{j}$ & 20.828 a-h & 38.489 qr & $11014.058 \mathrm{o}-\mathrm{t}$ & $4779.17 \mathrm{~d}-\mathrm{k}$ \\
\hline & IR 81025-B-347-3 & 59817.069 a & $1779.029 \mathrm{ab}$ & $16.039 \mathrm{q}$ & $95.275 \mathrm{a}-\mathrm{c}$ & 12734.312 h-k & $4582.17 \mathrm{~d}-\mathrm{m}$ \\
\hline & IR 81025-B-327-3 & $31611.007 \mathrm{~g}-\mathrm{i}$ & $796.7631-p$ & $19.759 \mathrm{i}-\mathrm{m}$ & $65.957 \mathrm{k}-\mathrm{n}$ & $13234.310 \mathrm{f}-\mathrm{i}$ & $5233.67 \mathrm{c}-\mathrm{g}$ \\
\hline & NADA & 29403.344 h-k & 817.727 j-p & $21.424 \mathrm{a}-\mathrm{d}$ & $78.572 \mathrm{f}-\mathrm{j}$ & $10088.007 \mathrm{~s}-\mathrm{u}$ & $3087.83 \mathrm{t}-\mathrm{x}$ \\
\hline & TAROM & $13544.244 \mathrm{uv}$ & $485.463 \mathrm{t}-\mathrm{v}$ & 19.161 k-n & $92.635 \mathrm{a}-\mathrm{d}$ & $15517.545 b c$ & $6066.33 \mathrm{a}-\mathrm{c}$ \\
\hline & VANDANA & $25170.8831-p$ & $1011.017 \mathrm{f}-\mathrm{i}$ & 20.998 a-g & 58.959 n-o & $11207.031 \mathrm{~m}-\mathrm{s}$ & 3531.67 o-w \\
\hline & IR 78908-193-B-3-B & $19648.587 \mathrm{r}-\mathrm{t}$ & $435.382 \mathrm{t}-\mathrm{V}$ & $19.278 \mathrm{k}-\mathrm{n}$ & $66.630 \mathrm{k}-\mathrm{n}$ & $12918.733 \mathrm{~g}-\mathrm{j}$ & $4479.83 \mathrm{f}-\mathrm{p}$ \\
\hline & IR 81429-B-31 & $32943.967 \mathrm{f}-\mathrm{h}$ & $537.236 \mathrm{r}-\mathrm{v}$ & $19.0931-n$ & $72.670 \mathrm{i}-1$ & $19291.015 \mathrm{a}$ & $5361.17 \mathrm{c}-\mathrm{f}$ \\
\hline & IR 78875-176-B-1-B & $25116.2491-p$ & 857.238 i-p & $20.690 \mathrm{~b}-\mathrm{i}$ & 91.469 a-e & $16032.245 b$ & $5113.33 \mathrm{c}-\mathrm{h}$ \\
\hline & IR 79971-B-202-2-4 & $37995.980 \mathrm{~d}$ & $1711.029 \mathrm{~b}$ & $21.500 \mathrm{a}-\mathrm{c}$ & $73.628 \mathrm{~h}-1$ & 13791.627 e-h & 4145.50 h-r \\
\hline & IR 80508-B-194-4-B & 22772.810 o-r & 850.746 i-p & 21.140 a-e & $62.7561-n$ & $10645.846 \mathrm{p}-\mathrm{u}$ & $4128.01 \mathrm{~h}-\mathrm{s}$ \\
\hline & IR 80508-B-194-3-B & $50118.397 \mathrm{bc}$ & 1062.977 e-h & $21.528 \mathrm{ab}$ & $68.704 j-n$ & 13803.437 e-h & $5398.83 \mathrm{c}-\mathrm{f}$ \\
\hline & IR 79907-B-493-3-1 & 21938.729 p-r & 950.264 f-m & $21.222 \mathrm{a}-\mathrm{e}$ & $46.124 \mathrm{pq}$ & $14028.987 \mathrm{~d}-\mathrm{g}$ & $5530.33 \mathrm{~b}-\mathrm{d}$ \\
\hline & IR 81025-B-347-3 & $58902.192 \mathrm{a}$ & $1521.026 \mathrm{c}$ & $16.995 \mathrm{p}$ & $59.972 \mathrm{~m}-\mathrm{o}$ & $15051.500 \mathrm{~b}-\mathrm{e}$ & $6362.55 \mathrm{ab}$ \\
\hline & IR 81025-B-327-3 & $30648.724 \mathrm{~g}-\mathrm{j}$ & $754.331 \mathrm{n}-\mathrm{q}$ & $20.518 \mathrm{c}-\mathrm{i}$ & $87.215 \mathrm{a}-\mathrm{f}$ & 14858.255 b-e & $6555.10 \mathrm{a}$ \\
\hline & NADA & 29024.263 i-1 & $760.457 \mathrm{n}-\mathrm{q}$ & $21.788 \mathrm{a}$ & $96.574 \mathrm{ab}$ & $11696.049 \mathrm{j}-\mathrm{q}$ & 4501.50 e-o \\
\hline & TAROM & $13431.251 \mathrm{uv}$ & $457.401 \mathrm{t}-\mathrm{v}$ & $19.975 \mathrm{~h}-1$ & $95.381 \mathrm{a}-\mathrm{c}$ & $15267.167 \mathrm{~b}-\mathrm{d}$ & $6024.11 \mathrm{a}-\mathrm{c}$ \\
\hline
\end{tabular}




\begin{tabular}{|c|c|c|c|c|c|c|c|}
\hline \multirow{12}{*}{ I3 } & VANDANA & 23477.248 n-r & $988.017 \mathrm{f}-\mathrm{k}$ & 20.953 a-h & $46.425 \mathrm{pq}$ & $12200.833 \mathrm{i}-\mathrm{o}$ & 4379.17 g-p \\
\hline & IR 78908-193-B-3-B & $17945.766 \mathrm{st}$ & 416.116 uv & $21.013 \mathrm{a}-\mathrm{g}$ & $86.203 \mathrm{~b}-\mathrm{g}$ & $13405.519 \mathrm{f}-\mathrm{i}$ & $4628.67 \mathrm{~d}-1$ \\
\hline & IR 81429-B-31 & 30560.788 g-j & $520.457 \mathrm{~s}-\mathrm{v}$ & 20.412 e-i & $82.346 \mathrm{~d}-\mathrm{i}$ & 14951.377 b-e & $5378.06 \mathrm{c}-\mathrm{f}$ \\
\hline & IR 78875-176-B-1-B & $24698.453 \mathrm{~m}-\mathrm{q}$ & $812.578 \mathrm{j}-\mathrm{p}$ & $20.327 \mathrm{e}-\mathrm{j}$ & $98.029 \mathrm{a}$ & $12398.370 \mathrm{i}-\mathrm{m}$ & $4978.66 \mathrm{~d}-\mathrm{j}$ \\
\hline & IR 79971-B-202-2-4 & 37012.584 de & $1270.463 \mathrm{~d}$ & $21.502 \mathrm{a}-\mathrm{c}$ & 49.913 ор & $14321.500 \mathrm{c}-\mathrm{f}$ & $3900.831-u$ \\
\hline & IR 80508-B-194-4-B & $21797.306 \mathrm{p}-\mathrm{s}$ & 835.733 i-p & $20.290 \mathrm{e}-\mathrm{j}$ & $32.242 \mathrm{rs}$ & 12744.667 h-k & $3628.16 \mathrm{~m}-\mathrm{v}$ \\
\hline & IR 80508-B-194-3-B & $47310.524 \mathrm{bc}$ & $975.877 \mathrm{f}-1$ & $21.158 \mathrm{a}-\mathrm{e}$ & $43.453 \mathrm{pq}$ & 12326.167 i-n & 4224.33 h-q \\
\hline & IR 79907-B-493-3-1 & 20758.809 q-s & 914.015 g-n & 20.890 a-h & $36.294 \mathrm{qr}$ & 13854.333 e-h & $5405.33 \mathrm{c}-\mathrm{f}$ \\
\hline & IR 81025-B-347-3 & $57791.145 \mathrm{a}$ & $1301.361 \mathrm{~d}$ & $16.147 \mathrm{q}$ & $70.094 \mathrm{j}-\mathrm{m}$ & $14768.333 \mathrm{c}-\mathrm{e}$ & 5484.67 b-e \\
\hline & IR 81025-B-327-3 & 27993.566 i-m & $687.603 \mathrm{p}-\mathrm{s}$ & 20.447 e-i & $46.615 \mathrm{pq}$ & $14761.667 \mathrm{c}-\mathrm{e}$ & $5055.01 \mathrm{~d}-\mathrm{i}$ \\
\hline & NADA & 27946.195 i-m & $615.270 \mathrm{q}-\mathrm{t}$ & $21.085 \mathrm{a}-\mathrm{f}$ & $84.555 \mathrm{c}-\mathrm{h}$ & $10910.500 \mathrm{p}-\mathrm{t}$ & 3147.67 s-x \\
\hline & TAROM & $12932.878 v$ & $431.748 \mathrm{t}-\mathrm{V}$ & $19.252 \mathrm{k}-\mathrm{n}$ & $81.328 \mathrm{e}-\mathrm{i}$ & 13849.167 e-h & 4368.66 g-p \\
\hline \multirow{12}{*}{ I4 } & VANDANA & 21687.729 p-s & 712.423 o-r & $20.065 \mathrm{~g}-\mathrm{k}$ & 41.059 p-r & 10704.833 p-u & $3922.33 \mathrm{k}-\mathrm{u}$ \\
\hline & IR 78908-193-B-3-B & 16629.824 tu & $381.106 \mathrm{v}$ & $20.085 \mathrm{f}-\mathrm{k}$ & $87.355 \mathrm{a}-\mathrm{f}$ & $11374.6091-\mathrm{s}$ & $4065.67 \mathrm{i}-\mathrm{t}$ \\
\hline & IR 81429-B-31 & 29948.589 h-k & $445.391 \mathrm{t}-\mathrm{V}$ & 19.823 i-m & $82.166 \mathrm{~d}-\mathrm{i}$ & 12709.711 h-k & $4811.83 \mathrm{~d}-\mathrm{k}$ \\
\hline & IR 78875-176-B-1-B & 24268.589 m-q & $781.343 \mathrm{~m}-\mathrm{q}$ & $18.955 \mathrm{mn}$ & $76.728 \mathrm{f}-\mathrm{k}$ & $9562.587 \mathrm{u}$ & $3325.66 \mathrm{q}-\mathrm{w}$ \\
\hline & IR 79971-B-202-2-4 & 35512.183 d-f & $1215.020 \mathrm{de}$ & $20.573 \mathrm{~b}-\mathrm{i}$ & $24.464 \mathrm{~s}$ & 12203.833 i-o & $3639.17 \mathrm{l}-\mathrm{v}$ \\
\hline & IR 80508-B-194-4-B & $21515.946 \mathrm{p}-\mathrm{s}$ & 802.573 k-p & $19.178 \mathrm{k}-\mathrm{n}$ & 36.112 qr & $9863.167 \mathrm{tu}$ & $1869.50 \mathrm{y}$ \\
\hline & IR 80508-B-194-3-B & $46747.940 \mathrm{c}$ & $951.835 \mathrm{f}-\mathrm{m}$ & $20.525 \mathrm{c}-\mathrm{i}$ & $36.568 \mathrm{qr}$ & 10591.833 p-u & $2939.01 \mathrm{u}-\mathrm{x}$ \\
\hline & IR 79907-B-493-3-1 & $19910.653 \mathrm{r}-\mathrm{t}$ & 879.244 h-o & 19.227 k-n & $23.443 \mathrm{~s}$ & $10330.500 \mathrm{r}-\mathrm{u}$ & $3660.67 \mathrm{l}-\mathrm{v}$ \\
\hline & IR 81025-B-347-3 & $56894.552 \mathrm{a}$ & $1202.527 \mathrm{de}$ & $16.033 \mathrm{q}$ & 50.997 op & $11098.167 \mathrm{n}-\mathrm{t}$ & $3167.33 \mathrm{r}-\mathrm{x}$ \\
\hline & IR 81025-B-327-3 & $26590.768 \mathrm{k}-\mathrm{o}$ & $603.010 \mathrm{q}-\mathrm{u}$ & $19.413 \mathrm{j}-\mathrm{n}$ & 41.773 p-r & $10451.500 \mathrm{q}-\mathrm{u}$ & $3497.67 \mathrm{p}-\mathrm{w}$ \\
\hline & NADA & 26974.818 j-n & 601.167 q-u & $20.493 \mathrm{~d}-\mathrm{i}$ & $70.285 \mathrm{j}-\mathrm{m}$ & $9600.500 \mathrm{u}$ & 2711.83 v-y \\
\hline & TAROM & $12500.909 \mathrm{v}$ & $409.359 \mathrm{v}$ & $18.060 \mathrm{o}$ & 50.984 op & $10587.833 \mathrm{p}-\mathrm{u}$ & $2607.50 \mathrm{w}-\mathrm{y}$ \\
\hline
\end{tabular}

Means in each column, followed by at least one similar letter(s) are not significantly different at $5 \%$ probability level using Duncan's Multiple Range Test

I1, I2, I3 and I4 include irrigation regimes of 1, 3, 5 and 7 days, respectively

However, the results corresponded to other studies (Lopes and Reynolds, 2010; Daxylem, 2016) on the reduction of traits size related to root anatomy such as central cylinder, which can reduce vascular bundles area by reducing the interior space in order to increase the efficiency of water (Table 5). Positive and significant correlation between central cylindrical area and xylem (0.667**) also showed increased likelihood of positive and negative impacts of these two traits in a line (Table 10). 
Table 10. Correlation coefficients between grain yield and root anatomy traits and yield components of rice genotypes

\begin{tabular}{c|c|c|c|c|c|c}
\hline & $\mathbf{1}$ & $\mathbf{2}$ & $\mathbf{3}$ & $\mathbf{4}$ & $\mathbf{5}$ & $\mathbf{6}$ \\
\hline 1. Grain yield & 1 & 0.092 & -0.020 & -0.032 & $0.249^{* *}$ & $0.672^{* *}$ \\
2. Area of central cylinder & & 1 & $0.677^{* *}$ & $-0.308^{* *}$ & -0.012 & 0.083 \\
3. Xylem area & & & 1 & -0.067 & -0.102 & -0.069 \\
4. Weight of one thousand seeds & & & & 1 & -0.020 & -0.080 \\
5. The fertility rate & & & & & 1 & $0.292^{* *}$ \\
6. Dry matter yield & & & & & & 1 \\
\hline
\end{tabular}

${ }^{*}$ and ${ }^{* *}$ : Significant at $5 \%$ and $1 \%$ probability levels, respectively

\section{Xylem area (posterior) of root}

The results of combine analysis showed that there was a statistically significant difference between the year, irrigation regimes and genotypes and interaction of irrigation regimes and genotypes at $1 \%$ level and was no significant difference with other factors (Table 7). Increasing irrigation intervals had negative effects on the xylem area (Table 8). Mean comparison of the interaction of two factors showed that genotypes IR 79971-B-202-2-4 and IR 78908-193-B-3-B had the highest and the lowest xylem areas in all irrigation regimes, respectively due to genetic reasons; like other genotypes, it decreased with increasing irrigation intervals (Table 9). Due to the task and nature of xylem vessels in transferring water and nutrients, it seems that more water was maintained in genotype IR 78908-193-B-3-B with high resistance. On the other hand, in the first irrigation regime (1-day interval) with relatively larger vessels $\left(985.616 \mu \mathrm{m}^{2}\right)$, water transfer and drain was faster, which is considered a positive factor in warm conditions of rice growing environment. Given that the movement of water in Xylem vessels is affected by water uptake (xylem vessels wall) or adhesive force in addition to cohesive force; therefore, capillary rise of water in xylem vessels depends on the angle of the liquid contacting the wall, xylem vessels' radius and surface tension of liquids as well as gravity force, because the capillary rise in vessels is inversely proportional with its radius as a result capillary force retaining water is higher with smaller xylem area, and more pressure is needed to move water in vessels, which can be the main cause of compatibility of genotypes with high resistance to drought conditions due to reduced xylem area and hence improving the photosynthetic efficiency and water consumption (Daxylem, 2016; Hamadanzadah et al., 2015). By this reason, water is maintained with more force in genotype IR 78908-193-B-3-B with smaller xylem area $\left(425.653 \mu^{2}\right)$. In this system, transpiration is a physical phenomenon to produce movement force for water and inorganic elements (McKenzie et al., 2009; Daxylem, 2016). Given the importance of this route, changes in the xylem area at the time of planting and according to different environmental conditions and the amount of irrigation can disrupt the absorption and transportation processes of water and nutrients to photosynthetic parts (Figure 2). Results correspond to Limouchi et al. (2013) about reduced xylem area with increased stresses, drought stress in this study (compared to favorable conditions at heading stage). 


\section{Number of xylem vessels in root}

According to Figures 2 and 3, number of xylem vessels in root was not affected by irrigation regimes and had a stable trend in all irrigation regimes and differences were due to internal factors and genetic reasons of investigated genotypes. Genotype IR 81025-B347-3 had the highest number with 8 xylem vessels in cross-section of root. It seems that this genotype could have a consistency to absorb and maintain more water with increased number and decreased area due to lower central cylinder area. The results corresponded to (Daxylem, 2016) that number of xylem vessels depends on internal factors of plants and would not be affected by surrounding environment such as irrigation.

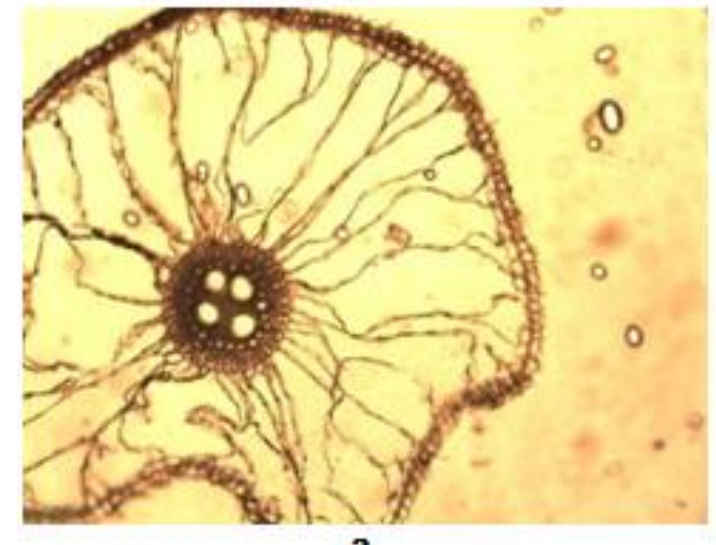

a

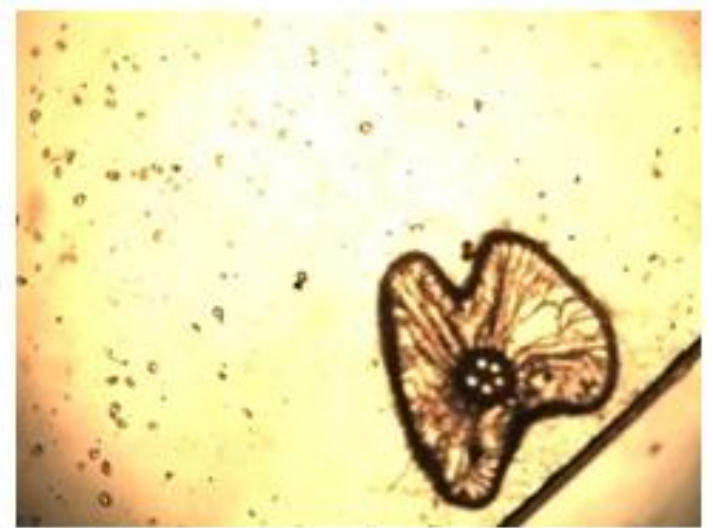

b

Figure 2. Root anatomy; $a$ and $b$ : cross-section of the root with a magnification of 40 and 10, respectively

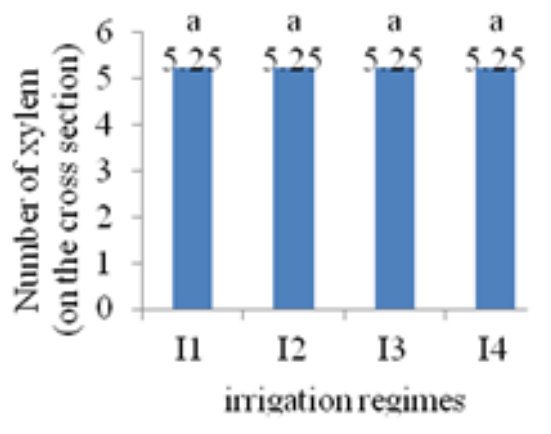

a

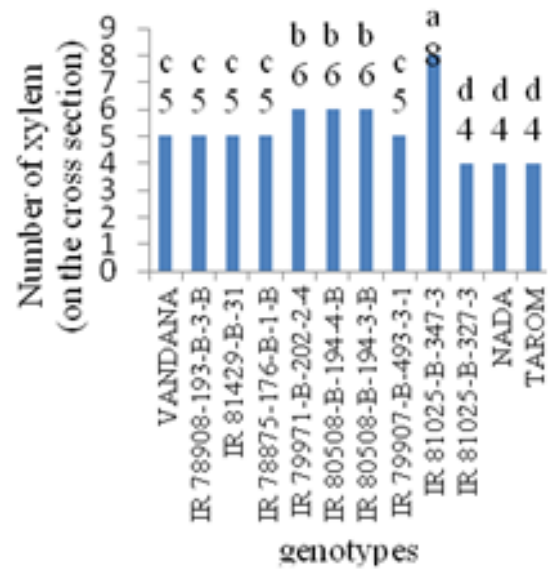

b

Figure 3. Number of posterior xylem bundles; $a$ and $b$ : number of vascular bundles in the different irrigation regimes and aerobic rice genotypes, respectively. I1, I2, I3 and I4 include irrigation regimes of $1,3,5$ and 7 days, respectively

\section{The weight of one thousand seeds}

The results of combined analysis showed that except for the interaction of year and irrigation regimes, other factors and the interaction between them had significant 
differences at $1 \%$ (Table 7). The highest and lowest weights of one thousand seeds were seen in the second irrigation regime (3-day interval) (20.394 g) and the fourth irrigation regime (7-day interval) (19.369 g), respectively (Table 8). As it can be seen, genotypes in 7-day interval irrigation regime had less weight of one thousand seeds in addition to reduced grain yield. The highest and lowest weights of one thousand seeds were achieved for Neda (21.788 g) in the second irrigation regime and genotype IR 81025-B347-3 (19.033 g), respectively. Increased capacity of active reservoir and more strength to provide assimilates to seed in particular by providing favorable conditions in 3-day interval irrigation regime for genotype Neda contrary to other genotypes can be the reasons for reaching this conclusion. The results corresponded to other researchers (Arvin and Vafabakhsh, 2016) about the relationship between source and reservoir in increased weights of one thousand seeds and increased strength in ideal irrigation to fill the reservoir (Table 9).

\section{Fertility rate}

The results of this study showed that there was significant difference between years, irrigation regimes and genotype at 5\% level and between the interaction of two factors at $1 \%$ level, but no difference was observed in other cases (Table 7). Mean comparisons represented the different reactions of genotypes to different irrigation regimes; despite the decline in fertility rate from the first to fourth irrigation regimes that actually represented the negative impact of increased drought on this trait. The highest and lowest fertility rate were seen in genotype IR 78875-176-B-1-B (98.029\%) in the third irrigation regime (5-day interval) and genotype IR 79907-B-493-3-1 (23.443\%) in the fourth irrigation regime (7-day interval), respectively. The result could be due to different responses of genotypes in the processes of production and accumulation of nonstructural carbohydrate soluble in vegetative parts of plants as well as panicle structure and its role in providing photosynthesis material in reproductive and vegetative parts and finally the harvest index. Soluble nonstructural carbohydrate plays an important role in the production of viable pollens, respiration rate and filling rate. It was found that by changing the irrigation regime and increasing fertility rate, the amount of soluble carbohydrates in vegetative parts at the time of physiological maturity had significantly declined (Tables 8 and 9). The results corresponded to others (Arvin and Vafabakhsh, 2016; Shanmugasundaram, 2015) about increased sterility due to high drought, the release and fertility of pollen role in fertility rate and the negative effects of high drought during maturity.

\section{Dry matter yield per hectare}

The results of this study showed that except for effects of years and genotypes as well as years, genotypes and irrigation regimes, other factors had significant differences. The interaction between years and irrigation regimes had significant differences at 5\% level and other factors were significantly different at $1 \%$ level (Table 7). Relative superiority of dry matter of studied genotypes in the 3-day, 5- day and 7day interval irrigation regimes and also genotypes with high resistance showed that changes in this trait fit perfectly with the grain yield (Table 8). Given that the highest grain yield was obtained in this irrigation regime and genotypes, it can be a result of increased leaf area index and net photosynthesis in order to transfer to the main reservoir (seeds). The highest $(19291.015 \mathrm{~kg} / \mathrm{ha})$ and lowest $(9562.587 \mathrm{~kg} / \mathrm{ha})$ dry 
matter per hectare was seen in genotype IR 81429-B-31 with high resistance in the 3day interval irrigation regime (Table 2) and genotype IR 78875-176-B-1-B in the 7-day interval irrigation regime, respectively (Table 9). In addition to grain yield, the results can be explained by genetic differences and their different responses to different irrigation regimes. Although the results are not consistent with (Ghasemi-Nasr et al., 2016), which stated flood irrigation increased dry matter, but corresponded to (Abdola and Zarea, 2015) about the reduction of dry matter in 1- day irrigation regime flooding) due to increased nutrients washing and making them unavailable for plants. The results are consistent with (Durand et al., 2016) on the reduction of nutrients accumulation to increase dry matter due to reduced plant growth period In terms of increased drought according to what happened in the fourth irrigation regime (7-day interval).

\section{Grain yield}

According to combined analysis results between years, irrigation regimes, their interactions as well as between genotypes and interaction of genotypes and irrigation regimes were significant at $1 \%$ level. However, there were no significant differences for the interaction of genotypes and year and the simultaneous effect of three factors and this indicates that grain yield was affected by genetic features, different irrigation regimes and their positive integration (Table 7). Mean comparisons showed that the highest grain yield $(5094.31 \mathrm{~kg} / \mathrm{ha})$ was related to the 3 -day interval irrigation regime, which had increased the production compared to flooding irrigation regimes (probably due to the incompatibility and waste of resistance energy such as the energy for creating aerenchyma) and also 5- and 7-day interval irrigation regimes (could be due to the unavailability to nutrients and assimilate accumulation at the base of plants) with rates of $19.50,10.72$ and $34.21 \%$, respectively or $993.52,546.05$ and $1742.79 \mathrm{~kg} / \mathrm{ha}$, respectively (Durand et al., 2016; Mohd Zain and Razi Ismail, 2016). Recent results according to others (Tarlera et al., 2015) indicated that the second irrigation regime and in the absence of water, 5-day interval irrigation regime might be appropriate to increase irrigation efficiency and reducing environmental pollutants such as methane. Besides, in addition to being compatible with most of the studied genotypes, permanent flooding conditions can wash nutrients and make them unavailable for plants. According to the reducing trend from first to fourth irrigation regimes, it seems that different reaction during different developmental stages due to the limited assimilates and shorter filling and grain growth periods are one of the reasons for reaching this conclusion (Table 8). Genotypes IR 81025-B-327-3 was superior to the other rice genotypes that the highest value $(6555.10 \mathrm{~kg} / \mathrm{ha})$ was belonged to the second irrigation regime (3-day interval). Escaping from the water stress by reducing plant height to 10$20 \mathrm{~cm}$, especially in the maturity period, as well as the allocation of more carbohydrates to the main reservoir are the reasons for compatibility and superiority of this genotypes. The interaction of two factors showed that according to other studies (Tavala et al., 2015) genotypes responses to different irrigation regimes regarding their tolerance threshold thus traits related to genotypes was different. Hence, all genotypes in the fourth irrigation regime due to the short growing season and thus Allocation of less carbohydrates and minerals transferred to the main tank and ultimately Reduction of the tank activity and dry matter accumulation capacity (capacity $\times$ number of seed), grains had the lowest yield (Table 9). The results are consistent with other studies (Durand et al., 2016) on the reduction of grain yield in terms of increased tension, higher than plant tolerance due to the growth disturbance during reproductive stage and lack of 
transferring and allocation of carbohydrates and sugars to the grain as well as other studies (Abdola and Zarea, 2015) based on yield loss in flooded conditions; however, it is not in accordance with study of Ghasemi-Nasr et al. (2016), which stated increasing available water for roots in flooded irrigation had increased rice yield.

The results of regression analysis of grain yield and traits showed that the lengths of stigma and style and xylem area are factors affecting grain yield; so that, $0.016 \%$ of the changes associated with $0.01 \%$ more than the style length was related to the stigma length, which in turn represents the role and importance of this trait compared to the traits in rice production. According to recent results, in order to achieve an optimum value for this index, creating a perfect reservoir can provide a base for transferring dry matter to the reservoir and the formation of economic performance in line with increased production (Table 11). The results corresponded to (Oyiga et al., 2010) about the effect of the stigma on grain yield due to its high influence on receiving pollen and fertilization.

Table 11. Stepwise regression analysis of grain yield and floret and root anatomical properties based on all the data

\begin{tabular}{c|c|c}
\hline Model & Partial $\mathbf{R}^{\mathbf{2}}$ & Model R \\
\hline $\mathrm{Y}=3827.462^{* * *}+0.455^{*} \mathrm{X}_{1}$ & 0.016 & 0.016 \\
$\mathrm{Y}=3981.436^{* * *}+0.649^{* *} \mathrm{X}_{1}-0.956^{*} \mathrm{X}_{2}$ & $0.016+0.015$ & 0.031 \\
$\mathrm{Y}=4321.589^{* *}+0.805^{* *} \mathrm{X}_{1}-1.317^{* *} \mathrm{X}_{2}-0.420^{\mathrm{ns}} \mathrm{X}_{3}$ & $0.016+0.015+0.01$ & 0.041 \\
\hline ns ${ }^{*}$ and ${ }^{* *}:$ Nonsignificant and significant at 5 and $1 \%$ level of probability, respectively \\
$\mathrm{X}_{1}=$ the stigma \\
$\mathrm{X}_{2}=$ the style \\
$\mathrm{X}_{3}=$ xylem area (Posterior)
\end{tabular}

\section{Conclusion}

The results of the present study indicated that the size of anatomical characteristics of florets was more dependent on internal properties of the plant; so that, genotypes with larger and smaller sizes of these traits maintained their preference to other genotypes while under the influence of different irrigation regimes. In general, increasing irrigation intervals from the second (3-day interval) to the fourth (7-day interval) irrigation regimes and thus increased drought around plants reduced pollen area and as a result nutrients reservation was also reduced that can reduce its transfer to ovaries and plants fertility rate. The first irrigation regime with one day rotation also in flood The IR 80508-B-194-4-B genotype had the highest grain pollen area in all irrigation regimes due to genetic reasons. Increasing the irrigation interval had a negative effect on the pollen grain surface due to reduced food and energy needed to reach ovaries that ultimately led to lack of fertility and reduced grain yield conditions, due to the aerobic nature of genotypes, reduced pollen grains due to more energy to expand the adaptive mechanisms such as arranchym. From the highest to the shortest anther length, the irrigation regimes were observed in intervals of five, seven, three and one days, respectively. The IR 78908-193-B-3-B genotype also had the highest anther length among all irrigation regimes, except for a significant decrease in the second irrigation regimen with a three-day rotation that could be a major factor in increasing fertility and grain yield was due to the proximity to the stigma and hence more effective grain 
transfer, but no significant difference was observed in other irrigation regimes. In the fourth irrigation regimen with a seven-day irrigation interval, we observed a decrease in anther width, but in other irrigation regimes there was no difference in width. The IR 80508-B-194-3-B genotype had the highest anther width in all studied irrigation regimes, which increased the irrigation intervals and, as a result, drought reduced. The highest length of the stigma was for IR 78875-176-B-1-B genotype in all irrigation regimes, which, like other genotypes, increased with increasing length of irrigation intervals. The length of the style in the fourth irrigation regimen with a seven-day interval decreased, and there was no significant difference in other irrigation regimes. The IR 78908-193-B-3-B genotype also had the highest length of style in all irrigation regimes, which increased the length of style by increasing irrigation intervals, so that it had the maximum length of style in the fourth irrigation regimen with irrigation interval of seven on the contrary to genotypes with less resistance and therefore more favorable compatibility with these conditions. Due to having a good-sized stigma, style, anther and anther width, the second irrigation regime was able to get and keep more pollen and thus increased fertility rate and grain yield. While in other irrigation regimes such as the fourth irrigation regime (7-day interval) with increased anthers and reduced style length, the distance between male and female organs increased and thus receiving pollen decreased. The results also showed water shortage in 5- and 7-day irrigation regimes caused a reduction in central cylindrical area and xylem area, which could be a mechanism to increase water use efficiency and reduce the transpiration. The results showed that the IR 81025-B-347-3 and IR 79971-B-202-2-4 genotypes had the highest values for all the irrigation regimes in the central cylindrical and xylem area crests, respectively. By increasing the irrigation intervals and thus the drought around the plant to adapt to the conditions and increase the efficiency of use, the potential and the transfer of water from the surface were reduced. As a result, the dryness around the plant was reduced to adapt to the conditions and to increase the efficiency of use, the potential and the transfer of water from their surface. Of course, it could lead to a reduction of material transferring and ultimately grain yield such as that obtained for the fourth irrigation regime (7-day interval). Among the traits dependent on yield and grain yield components, weight of a thousand seeds dry matter and seed yield were highest to the lowest in irrigation regimes of three, five, one and four days, respectively. Fertility also increased the irrigation intervals due to reduced pollen grains and lack of energy to reach the ovary and to inoculate. NADA genotype had the highest weight of a thousand seeds in irrigation regimes of one and three days and the IR 79971-B-202-2-4 genotype had the highest amount in irrigation regimes of five and seven days. Increasing the weight of a thousand seeds in low-resistance genotypes in conditions of increasing irrigation intervals over the previous discussion could result in a reduction in the number of florets and more infertility, thereby reducing competition and increasing the space in the paniculum. The IR 78908-193-B-3-B genotype had the highest fertility rates in first and fourth irrigation regimes, with one and four-day irrigation intervals, NADA and IR 78875-176-B-1-B genotypes also had the highest fertility rates, respectively in the second and third irrigation regimes with irrigation intervals of three and five days according to the previous descriptions. Due to the large canopy structure, large leaves and thick stems, IR 81429-B-31 genotype with the highest dry resistance had the highest dry matter yield in all irrigation regimes. The TAROM, IR 81025-B327-3, IR 81025-B-347-3 and IR 81429-B-31 genotypes have the highest grain yield in irrigation regimes of one, three, five and seven days, respectively. Resistant genotypes 
with improved resistance to irrigation intervals maintained their grain yield better than less resistant genotypes. However, under daily irrigation conditions due to increased energy, resistance to other genotypes had lower grain yield, which could be used depending on the different moisture conditions. The results of this study indicated that the second irrigation regimen with three-day irrigation interval was able to adapt the aerobic rice genotypes with the highest positive and significant correlation with grain yield and decrease the negative correlation traits. Finally, the relative yield of genotypes was increased. The IR 81025-B-327-3 genotype with an average of $10.6555 \mathrm{~kg} / \mathrm{h}$ in the second irrigation regimen had the highest grain yield and could be recommended as the superior genotype for cultivation in similar conditions.

Therefore, it can be suggestions for further studies that by focusing main goals on reducing the central cylinder area and xylem of root to increase water use efficiency in dry condition and controlling lengths of florets parts we can hop to increase connection between pollen and flower and finally fertility to increase production under different irrigations.

\section{REFERENCES}

[1] Abdola, A. A., Zarea, M. J. (2015). Effect of mycorrhiza and root endophytic fungi under flooded and semi-flooded conditions on grain yield and yield components of rice. - Crop Production 8(1): 223-230.

[2] Akbari, A., Capping, A., Borzooei, A., Majdabadi, A. (2010): Evaluation of wheat genotypes morphological changes in salinity stress conditions. - Journal of Science and Technology of Greenhouse Culture 1(4): 71-82.

[3] Akbari, S., Kafi, M., Rezvan Beidokhti, S. (2016): The effect of drought stress on yield, yield components and anti-oxidant of two garlic (Allium sativum L.) ecotypes with different planting densities. - Journal of Agroecology 8(1): 95106.

[4] Anonymous. (1982): Annual Report. - International Rice Research Institute, Los Banos, Philippines.

[5] Arvin, P., Vafabakhsh, J. (2016): Study of drought and plant growth promoting rhizobacteria (PGPR) on radiation use efficiency and dry matter partitioning into pod in different cultivars of Brassica oilseed rape. - Journal of Agroecology 8(1): 134-152.

[6] Carmelita, M., Albertoa, R., Wassmanna, R., Hiranob, T. Miyatac, A., Hatanob, R., Kumara, A., Padrea, A., Amante, M. (2011): Comparisons of energy balance and evapotranspiration between flooded and aerobic rice fields in the Philippines. Agricultural Water Management 98: 1417-1430.

[7] Dong, N. M., Brandt, K. K., Sørensen, J., Hung, N. N., Hach, C. V., Tan, P. S., Dalsgaard, T. (2012): Effects of alternating wetting and drying versus continuous flooding on fertilizer nitrogen fate in rice fields in the Mekong Delta, Vietnam. - Soil Biol Biochem 47: 166-174.

[8] Durand, M., Porcheron, B., Hennion, N., Maurousset, L., Lemoine, R., Pourtau, N. (2016): Water deficit enhances $C$ export to the roots in Arabidopsis thaliana plants with contribution of sucrose transporters in both shoot and roots. - Plant Physiology 170(1): 1460-1479.

[9] Ghasemi-Nasr, M., Karandish, F., Naft-Chali, A. D., Mokhtasa-Bigdali, A. (2016): Effect of two periods of mid-season drainage on growth parameters of two rice varieties. Journal of Water Research in Agriculture 29(4): 419-431.

[10] Ghorbani, A., Zarinkamar, F., Fallah, A. (2011): Effect of cold stress on anatomical and morphological traits in both resistant and susceptible rice varieties at germination stage. Journal of Cells and Tissues 2(3): 235-244. 
[11] Ghosh, B., Chakma, N. (2015): Impacts of rice intensification system on two C. D. blocks of Barddhaman district, West Bengal. - Current Science 109(2): 342-346.

[12] Han, X. B., Li, R. Q., Wang, J. B. (1997): Cellular structural comparison between different thermo resistant cultivars of Raphanus sativus L. under heat stress. - J Wuhan Bot Res 15: 173-178.

[13] Jagadish, S. V. K., Craufurd, P. Q., Wheeter, T. R. (2007): High temperature stress and spikelet fertility in rice (Oryza Sativa. L.). - J Exp Bot 58: 1627-1635.

[14] Kulkarni, M., Phalke, S., (2009): Evaluating variability of root size system and its constitutive traits in hot pepper (Capsicum annum L.) under water stress. - Scientia Horticulturae 120: 159-166.

[15] Limouchi, K. (2013): Effect of different planting dates on the anatomy of the flag leaf and grain yield of rice varieties in the Khuzestan region, Iran. - International Journal of Biology 2(2): 19-27.

[16] Limouchi, K., Farahvash, F. (2014): Effect of different planting dates on anatomy of the peduncle and grain yield of rice varieties in the North Khuzestan region. - Ind J Sci Res and Tech 2(2): 99-103.

[17] Limouchi, K., Siadat, S. A., Gilani, A. (2014): Effect of planting date on vegetative growth and yield of three rice cultivars in north regions of Khuzestan. - Agronomic Research in Semi Desert Regions 11(1): 51-63.

[18] Lopes, M. S., Reynolds, M. P., (2010): Partitioning of assimilates to deeper roots is associated with cooler canopies and increased yield under drought in wheat. - Functional Plant Biology 37: 147-156.

[19] Majd, A., Jonobi, P., Zanipour, M. (2009): Effects of drought stress on anatomical structure of the sunflower plant. - Developmental Biology 1(4): 11-24.

[20] Mamnan, M. A., Bhuiya, M. S. U., Hossain, A. M. A., Akhand, D. (2009): Study on phenology and yielding ability of Basmati Fine Rice genotypes as influenced by planting date in Aman Eason, Bangladesh. - J Agril Res 34(3): 373-383.

[21] Matsui, T., Hisashi, K. (2003): Characteristics of floral organs related to reliable selfpollination in rice (Oryza Sativa L.). - Annals of Botany 91: 473-477.

[22] Matsui, T., Omasa, K. (2002): Rice (Oryza Sativa L.) cultivars tolerant to high temperature at flowering: anther characteristics. - Annals of Botany 89: 683-687.

[23] Matsui, T., Omasa, K., Horie, T. (2000): High temperature at flowering inhibit swelling of pollen grains, a driving force for thecae dehiscence in rice (Oryza sativa L.). - Plant Production Science 3: 430-434.

[24] Mckenzie, B. M., Bengough, A. G., Hallett, P. D., Thomas, W. T. B., Forster, B., Mcnicol, J. W. (2009): Deep rooting and drought screening of cereal crops: a novel fieldbased method and its application. - Field Crops Research 112: 165-171.

[25] Metcalf, C., Chalk, R. (1950): Anatomy of the Dicotyledons, Vol 3. - Clarenden Press, Oxford.

[26] Mohd-Zain, N. A., Razi-Ismail, M. (2016): Effects of potassium rates and types on growth, leaf gas exchange and biochemical changes in rice (Oryza sativa) planted under cyclic water stress. - Agricultural Water Management 164(1): 83-90.

[27] Mosavy, S. A., Khaledian, M. R., Ashrafzadeh, A., Shahinrokhsar. P. (2016): Effects of limited irrigation on yield and water productivity increasing of three soybean genotypes in Rasht region. - Journal of Water Research Agriculture 29(4): 433-446.

[28] Mostajeran, A., Rhimi-Eichi, V. (2008): Drought stress effect on root anatomical characteristics of rice cultivars (Oryza sativa L). - Pakistan Journal of Biological Science 11(18): 2173-2183.

[29] Oyiga, B. C., Uguru, M. I., Aruah, C. B. (2010): Studies on the floral traits and their implications on pod and seed yields in bambara groundnut (Vigna subterrenea $(L$.) Verdc). - Australian Journal of Crop Science 4(2): 91-97.

[30] Pandey, A., Kumar, A., Pandey, D. S., Thongbam, P. D. (2014): Rice quality under water stress. - Indian Journal of Advances in Plant Research 1(2): 23-26. 
[31] Park, G. H., Kim, J. H., Kim, K. M. (2014): QTL analysis of yield components in rice using a cheongcheong/nagdong doubled haploid genetic map. - American Journal of Plant Sciences 5: 1174-1180.

[32] Sadat-Jamali, S., Borzooei, A., Paknejad, F. (2014): Characterization root of sodium to potassium ratio and grain yield of seven wheat genotypes under salt stress. - Journal of Science and Technology of Greenhouse Culture 5(20): 165-175.

[33] Sedaghat, N., Pirdashti, H., Asadi, R., Mousavi-Taghani, Y. (2015): Effect of different irrigation methods on rice water productivity. - Journal of Water Research in Agriculture 28(1): $1-9$.

[34] Shanmugasundaram, B. (2015): Adoption of system of rice intensification under farmer participatory action research programme (FPARP). - Ind Res J Ext Edu 15(1): 114-117.

[35] Shelden, M. C., Roessner, U., Sharp, R. E., Tester, M., Bacic, A. (2013): Genetic variation in the root growth response of barley genotypes to salinity stress. - Funct Plant Biol 40(5): 516-530.

[36] Sing, R. P., Brennan, J. P., Farrell, T., Williams, R., Reinke, R., Lewin, L., Mullen, J. (2005): Economic Analysis of Improving Cold Tolerance in Rice in. Australia. Cooperative Research Centre for Sustainable Rice Production, Australia.

[37] Song, Z. P. (2001): A study of pollen viability and longevity in Oryza rufipogon, O. sativa, and their hybrids. - International Rice Research Notes 26: 31-32.

[38] Suzuki, S. (1981): Cold tolerance in rice plants with special reference to the floral characters. II. Relations between floral characters and the degree of cold tolerance in segregating generation. - Japanese Journal of Breeding 32:9-16.

[39] Tarlera, S., Capurro, M. C., Irisarri, P., Scavino, A. F., Cantou, G., Roel, C. (2015): Yield-scaled global warming potential of two irrigation management systems in a highly productive rice system. - Scientia Agricola 73(1): 43-50.

[40] Tavala, R., Aalami, A., Sabouri, H., Sabouri, A. (2015): Evaluation of haplotype and allelic diversity of SSR markers linked to major effect QTL on chromosome 9 controlling drought tolerance in rice. - Cereal Research 5(1): 107-119.

[41] Takeoka, Y., Almamun, A., Wada, T., Kaufman, P. B. (1992): Primary Features of the Effect of Environmental Stress on Rice Spikelet Morphogenesis. - In: Reproductive Adaptation of Rice to Environmental Stress, pp. 113-141. Developments in Crop Science Vol. 22. Scientific Societies Press/Elsevier, Tokyo.

[42] Tuyen, D. D., Prasad, D. T. (2008): Evaluating difference of yield trait among rice genotypes (Oryza sativa L.) under low moisture condition using candidate gene markers. - Omonrice 16: 24-33.

[43] Uphoff, N., Kassam, A., Thakur, A. (2013): Challenges of increasing water saving and water productivity in the rice sector: introduction to the system of rice intensification (SRI) and this issue. Taiwan J Water Conserv 61: 1-13.

[44] Zheng, G. L., Yun, L. I., Shun-tang, C., Hua, Z., Guo-hua, L. (2009): Effects of high temperature stress on microscopic and ultrastructural characteristics of mesophyll cells in flag leaves of rice. - Rice Sci 16: 65-71.

[45] Zhou, Y. Z. H., He, X. X., Sui, X. C., Xia, X., Zhang, K., Zhang, G. S. (2007): Genetic improvement of grain yield and associated traits in the northern China winter wheat region from 1960 to 2000. - Crop Science 47: 245-253. 